\title{
13. SEDIMENTARY AND DIAGENETIC EVOLUTION OF MESSINIAN EVAPORITES IN THE TYRRHENIAN SEA (ODP LEG 107, SITES 652, 653, AND 654): PETROGRAPHIC, MINERALOGICAL, AND STABLE ISOTOPE RECORDS ${ }^{1}$
}

\author{
Catherine Pierre ${ }^{2}$ and Jean Marie Rouchy ${ }^{3}$
}

\begin{abstract}
The Messinian evaporitic succession recovered at ODP Sites 652, 653, and 654 in the Tyrrhenian Sea was generated under various environmental conditions which ranged from brackish to hypersaline, as deduced from the sedimentary facies and stable isotope compositions of the carbonate and sulfate deposits. Water in the basins had to be shallow to undergo such rapid and large geochemical variations.

The marine influence was omnipresent in the basin at least during the deposition of sulfate evaporites; seawater or marine brines might have been supplied either by direct input into evaporitic lagoons as at Sites 653 and 654 , or by subterraneous infiltration in marginal areas as at Site 652.

Episodes of severe dilution by continental waters occurred frequently throughout Messinian times in the more basinal areas at Sites 653 and 654, while a fresh water body was standing permanently at Site 652 .

The high heat flow present at Site 652 was responsible for a major late authigenesis of iron-rich dolomites, which was initiated during the subsidence of the basin and ended before Pliocene.
\end{abstract}

\section{INTRODUCTION}

During the ODP Leg 107 cruise in the Tyrrhenian Sea, Messinian sediments were recovered at Sites 652,653 , and 654 below Pliocene-Pleistocene marine oozes, at sub-bottom depths of 188 $\mathrm{m}, 216 \mathrm{~m}$, and $242 \mathrm{~m}$, respectively (Fig. 1). However, the total recovery of these series, as well as their sedimentary facies, differs significantly at each site. The whole Messinian section drilled at Site 654 was revealed as incomplete as deduced from magnetostratigraphy (Kastens, Mascle, et al., 1987); it reaches a total thickness of $106 \mathrm{~m}$ and constitutes a succession of massive beds of sulfate evaporites intercalated with marls, sandstones, and limestones containing marine nannofossils. About $50 \mathrm{~m}$ of the uppermost Messinian deposits was recovered at Hole 653B; they include calcareous to dolomitic muds which contain marine nannofossils, goethite-rich oozes, silts, and sands, with gypsum occurring as isolated crystals or as individual beds several decimeters thick. At Site 652, below the lower Pliocene sediments, the barren homogeneous sequence attributed to the Messinian is made of $533 \mathrm{~m}$ of calcareous-dolomitic mudstones, siltstones, and sandstones, intercalated with nodular gypsum/anhydrite layers. These deposits were interpreted as being lacustrine, owing to their total lack of organisms, thus suggesting their contemporaneity with the late Messinian "lago mare" episode (Kastens, Mascle, et al.,1986), although they might have covered a longer time-span.

Petrography, mineralogy, and stable isotope techniques have been applied to study these Messinian carbonate and sulfate deposits, in an attempt to recognize and understand the sedimentary and diagenetic record of the evaporitic event. Furthermore, comparison of these results with the previous and abundant data on other Messinian evaporite occurrences from the Mediterranean area (deep sea sites of DSDP Legs 13 and $42 \mathrm{~A}$, and

${ }^{1}$ Kastens, K. A., Mascle, J., et al., 1990. Proc. ODP, Sci. Results, 107: College Station, TX (Ocean Drilling Program).

2 (CNRS-UA 388) Université Pierre et Marie Curie, Département de Géologie Dynamique, 4 Place Jussieu, 75252 Paris Cedex 05, France.

3 (CNRS-UA 1209) Muséum National d'Histoire Naturelle, Laboratoire de Géologie, 43 rue Buffon, 75005 Paris, France. land outcrops) will place the deposition of evaporites in the central Tyrrhenian Sea into the environmental and geodynamic context of the whole basin.

\section{ANALYTICAL PROCEDURES}

The petrographic study has used classical optical observations on thin sections for all the sulfate samples and about 50 samples of carbonate-bearing sediments. A few samples were selected for SEM observations, sometimes coupled with ORTEC analysis. Bulk mineralogy was determined systematically on each sample by $\mathrm{x}$-ray diffraction, primarily in order to recognize the nature of the carbonate and sulfate minerals, and to quantify the calcite-to-dolomite ratio in mixed carbonate assemblages.

Stable isotope measurements were performed on carbonates for ${ }^{18} \mathrm{O}$ and ${ }^{13} \mathrm{C}$, and on sulfates for ${ }^{18} \mathrm{O}$ and ${ }^{34} \mathrm{~S}$. Carbonate-bearing sediments were first washed with distilled water to remove soluble salts, and dried; then, samples were prepared using the classical method of attack at $25^{\circ} \mathrm{C}$ with $100 \%$ phosphoric acid (McCrea, 1950). For sediments containing mixtures of calcite and dolomite, more complex operations were developed. The $\mathrm{CO}_{2}$ released after 20 min of reaction with phosphoric acid was considered as coming solely from calcite (Clayton et al., 1968). Dolomite was isolated from the carbonate mixture after $15 \mathrm{~min}$ of reaction in $1 \mathrm{~N}$ acetic acid. X-ray diffraction was performed on the remaining fraction in order to control on the one hand the degree of decomposition of calcite, and on the other hand whether the reaction has or has not caused some damage to the crystal lattice of dolomite. In most samples from Site 652 which include a near stoichiometric dolomite associated with a nonstoichiometric dolomite, the fraction remaining after acetic acid reaction always contained the unique stoichiometric dolomite. The isotopic composition of the nonstoichiometric dolomite may be evaluated theoretically by simple mass-balance calculation using the $\delta$ values of calcite, stoichiometric dolomite, and bulk carbonate; the ratio of calcite to total dolomite; and the ratio of stoichiometric dolomite to nonstoichiometric dolomite.

$$
\delta_{\text {tot. dol. }}=\delta_{\text {bulk carb. }}-\left(\delta_{\text {calc. }}\right) \cdot \mathrm{x} /(1-\mathrm{x})
$$

tot. dol. = stoichiometric dolomite + nonstoichiometric dolomite calc. $\quad=$ calcite

bulk carb. $=$ calcite + stoichiometric dolomite + nonstoichiometric dolomite

$\mathrm{x}=$ fraction of calcite relative to total dolomite.

$$
\delta_{\text {n.s.dol. }}=\delta_{\text {tot. dol. }}-\left(\delta_{\text {s.dol }}\right) \cdot \mathrm{y} /(1-\mathrm{y})
$$




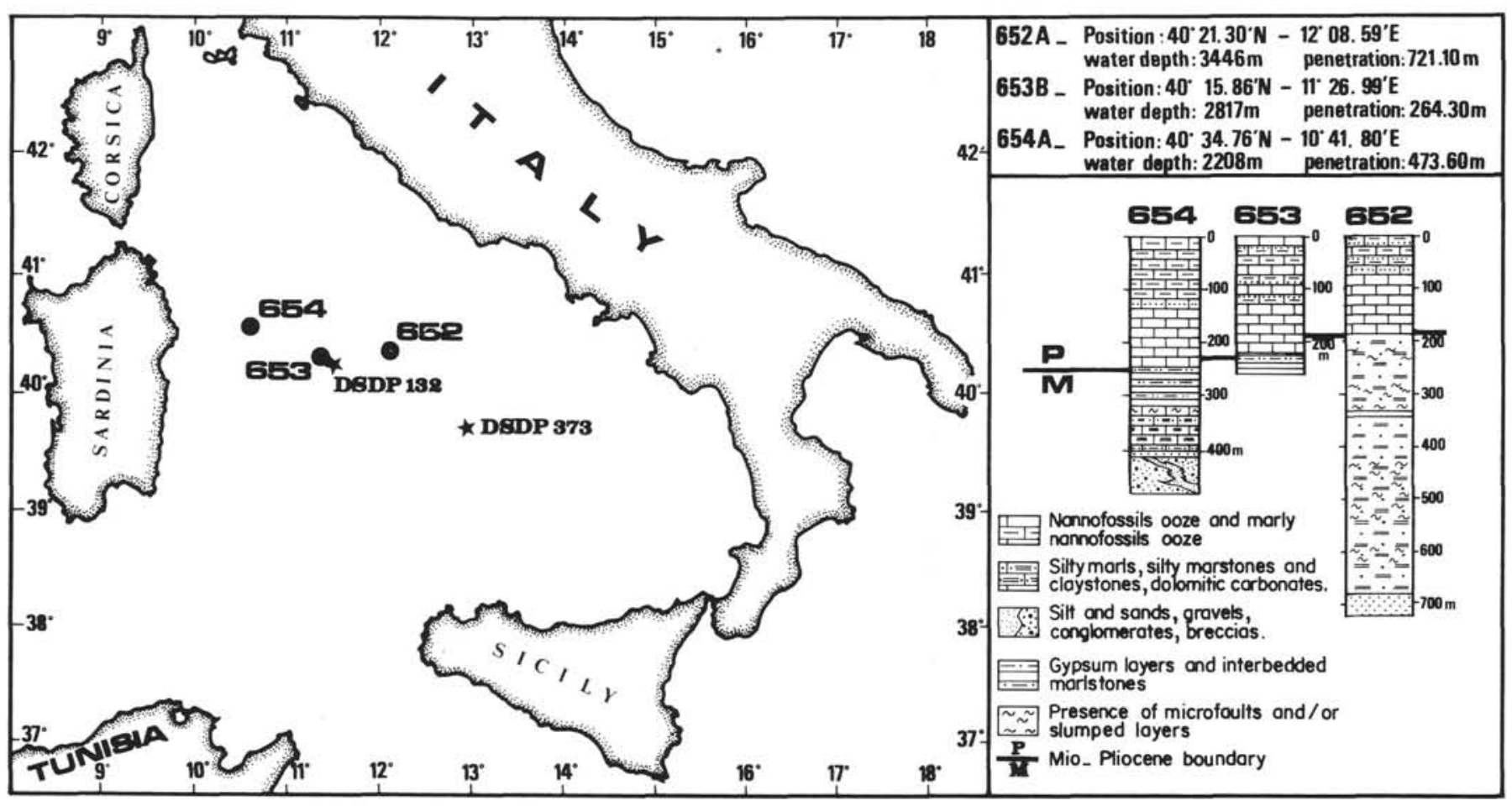

Figure 1. Location map of the ODP Leg 107 Sites 652, 653, and 654 with corresponding simplified lithological sequences.

n.s.dol $=$ nonstoichiometric dolomite

s.dol. = stoichiometric dolomite

y $\quad=$ fraction of stoichiometric dolomite relative to nonstoichiometric dolomite.

However, application of these mass-balance equations to the samples from Site 652 has failed because of uncertainties, often larger than $10 \%$, in the ratios between the dolomite phases.

Gypsum and anhydrite samples were first converted to barium sulfate, which was then mixed with graphite, and heated to $1100^{\circ} \mathrm{C}$ to produce $\mathrm{CO}_{2}$ for ${ }^{18} \mathrm{O}$ analysis (Longinelli and Craig, 1967). The remaining barium sulfide was converted to silver sulfide, which was oxidized to $\mathrm{SO}_{2}$ by burning in pure oxygen (Filly et al., 1975). Interlaboratory comparison for ${ }^{18} \mathrm{O}$ and ${ }^{34} \mathrm{~S}$ measurements of sulfate was made using the $\mathrm{BaSO}_{4}$ international reference OGSI-005 provided by Professor Sakai which has given $\delta^{18} \mathrm{O}$ value of $+9.3 \%$ relative to SMOW and $\delta^{34} \mathrm{~S}$ value of $+20.2 \%$ relative to C.D.T.; reproducibility of $\delta^{18} \mathrm{O}$ measurements was controlled by regular analysis of an internal $\mathrm{BaSO}_{4}$ reference prepared from Mediterranean seawater which has a mean value of $+9.5 \%$ relative to SMOW.

Both $\mathrm{CO}_{2}$ and $\mathrm{SO}_{2}$ gas produced from carbonates and sulfates were analyzed on a triple collector mass spectrometer (ISOGAS-SIRA 9) with an analytical precision $(2 \sigma)$ close to $0.03 \pm 0.02 \%$, Reproducibility is within the range $\pm 0.1 \% 0$ for ${ }^{18} \mathrm{O},{ }^{13} \mathrm{C}$, and ${ }^{34} \mathrm{~S}$ measurements. The $\delta$ values are given relative to the $\mathrm{PDB}$ reference for ${ }^{18} \mathrm{O}$ and ${ }^{13} \mathrm{C}$ of carbonates, to the SMOW reference for ${ }^{18} \mathrm{O}$ of sulfates, and to the CDT reference for ${ }^{34} \mathrm{~S}$ of sulfates. The $\delta^{18} \mathrm{O}$ values of dolomite were corrected by $-0.8 \%$ which corresponds to the isotope fractionation between dolomite and calcite which occurs during $\mathrm{CO}_{2}$ extraction by phosphoric acid (Sharma and Clayton, 1965).

\section{RESULTS}

\section{Sites 653 and 654}

\section{Sulfates}

\section{Petrography and Mineralogy}

The petrofacies of laminated gypsum groups several types of gypsum with planar to wavy, millimeter to centimeter lamina- tions; gypsum laminae are intercalated with marls, limestones, and occasionally biogenic layers. Two main groups are distinguished by petrographic criteria.

The regular-laminated "balatino" type gypsum: this typical structure is a composite repetitive lamination with three characteristic elements, generally with reverse-graded bedding; a basal portion with inclusion-rich, fine-grained gypsum (10-50 $\mu \mathrm{m})$, a middle portion with small to middle crystal size, and a coarsegrained $(100-250 \mu \mathrm{m})$ upper portion $(\mathrm{Pl} .1,1)$. The lamination is often regular, but it may be disrupted by discontinuities such as erosional surface, cross-bedding, and intercalation of detritic gypsum layer. Crystal habits are dominantly granular to prismatic, rarely acicular, and xenotypic to idiomorphic. At the top of the laminae, the gypsum crystals may either project into the overlying detritic intercalation suggesting further recrystallization of the largest crystals, or be truncated due to probable erosion effects (PI. 1, 2). Numerous layers show the typical crystalline structure of reworked detrital gypsum where elongated crystals lie more or less parallel to the bedding. The mineral composition of the nonevaporitic intercalations of claystones, siltstones, or marlstones includes mostly quartz, clays, feldspars, and carbonates (calcite and dolomite), and occasionally reworked organisms (foraminifers and nannoplankton). In a few levels, these intercalations consist of subautochthonous biogenic components, such as at $653 \mathrm{~B}-25 \mathrm{X}-1,68-70 \mathrm{~cm}$, where the carbonate partings are exclusively made of an accumulation of small monospecific coccoliths (about $3 \mu \mathrm{m}$ ) presumably Reticulofenestra sp. (Pl. 1, 3).

Another type of laminated gypsum is composed by alternations of 3-mm-thick layers of white gypsum and white powdery laminae of biogenic components. This facies, observed only in the Sample 654A-34R-4, 33-34 cm, appears very similar to some typical "balatino" of the Messinian of Sicily (Ogniben, 1957; Rouchy, 1976, 1982; Schreiber, 1974). The microstructure of this gypsum interval shows a reverse-graded arrangement of acicular crystals lying parallel to the bedding. The intergypsum films consist of a mixture of coccoliths, diatoms, and filamentous to coccoid undetermined forms (Pl. 1, 4). As in the balatino gyp- 
sum from Sicily, most of coccoliths are dwarf forms (as large as $1 \mu \mathrm{m})$ and have taxonomic affinities with Coccolithus sp. Diatom assemblages appear more diversified than coccoliths, with both centric and pennate forms; the largest forms are generally broken and present traces of dissolution, while the smallest forms are well-preserved. The population is mainly composed of various euryhaline species (Brachysira, Mesodiction, Mastogloia). The filaments with a diameter of $0.25 \mu \mathrm{m}$ appear as isolated spheres or aggregates, in some cases arranged in a pseudoregular structure (Pl. 2, 1); they are located in the intercrystalline voids and may also be partly included in the crystals (Pl. 2, 2). Size and morphology of these filaments suggest bacteria rather than algae. Enigmatic grains of $0.2-0.5 \mu \mathrm{m}$, possibly bacterial clusters of globular and occasionally annular structures (1$10 \mu \mathrm{m}$ in diameter), overlie or are included within the crystals (Pl. 2, 3). Foraminifers are frequently observed in the lower part of the laminae (Pl. 2, 4).

The regular laminated "balatino"-type gypsum is similar to that observed in the Messinian of numerous land sections and of Leg 13 and 42A DSDP sites. Genesis of this type of gypsum has been discussed by many authors: some of them consider a periodical precipitation of gypsum during seasonal concentration of marine waters (Ogniben, 1955) while others favor the detrital origin of the lamination (Garrison et al., 1978) and also gypsum reworking during storms (Hardie and Eugster, 1971). Petrographic observations of the gypsum from ODP Sites 653 and 654 show obviously that balatino gypsum may not have a unique mode of deposition. Several typical detrital structures and microstructures (erosional surfaces, ripples and cross-bedded structures, flat-lying reworked crystal fragments) are often observed at ODP Site 653 and DSDP Site 132; however, these structures do not necessarily imply a long-distance transport but rather a local reworking by currents or fresh water influx. Furthermore, gypsum clasts may come partly from the destruction of crystalline crusts developed at the margins of evaporitic ponds. This interpretation may not be applied to the laminated gypsum which is characterized by regular biogenic intercalations as shown at levels 654A-34R-4, 33-34 cm, and 654A-35R, CC (7-9 cm). As in some typical Sicilian "balatino," the exclusive presence of coccoliths in the nongypsum intercalations, and the concurrent changes of lithology and size of coccoliths, indicate clearly that the gypsum-carbonate rhythms are the result of periodical changes in the brine concentration (Rouchy, 1976); episodic (seasonal?) decreasing concentration of marine brines by influx of marine or continental waters may have induced sporadic blooms of flora (coccoliths, diatoms), followed by the crystallization of gypsum during the next high concentration stage. Interstitial precipitation of gypsum may have also occurred very early in the uppermost part of the new deposit. In that context, the periodic reworking and redeposition of gypsum crystals by currents during flooding episodes is easy to explain.

In the wavy contorted layered gypsum, the fabric of gypsum layers varies from simple wavy to subnodular, including more or less discontinuous lensoid forms (Pl. 3,1); the thickness of individual gypsum layers ranges generally between 1 and $3 \mathrm{~mm}$, and reaches $1 \mathrm{~cm}$ in some cases. The simplest microstructure consists of alternations of two forms of gypsum separated by discontinuities (e.g., 654A-33R-1, 80-82 cm): one form is composed by fine-grained gypsum associated with variable proportions of impurities; the second form consists of an aggregate of interlocking anhedral to euhedral coarse crystals (PI. 3, 2). In rare cases (e.g., 654A-28R-1, 64-67 cm), gypsum crystals display a discrete orientation subperpendicular to the bedding, suggesting that these "selenite" crystals were precipitated in situ. This microstructure may be complicated by the presence of additional silty to micritic interlayers, either at the top of the coarser gypsum layers or intercalated between the two gypsum forms, giving a second-order lamination.

Three modes of relation between the gypsum and nongypsum laminae are observed where: (1) the top of the gypsum laminae is truncated and the microtopography is filled by small gypsum grains and terrigenous components, interpreted as erosional and dissolution features that occurred periodically during deposition; (2) the top of gypsum crystals projects upward, deforms, and sometimes includes the nongypsum components, indicating early diagenetic crystallization or overgrowths of gypsum; and (3) typical chevron structures (Pl. 3, 3) are apparent by lines of impurities along growth zoning of gypsum crystals (e.g., 654A28R-1, 64-67 cm). These different modes are sometimes observed together in the same layer, thus suggesting variable physicochemical conditions during gypsum sedimentation.

Lenticular gypsum crystals of various sizes, locally clustered, often develop in the thickest micritic laminae. Most of these gypsum crystals display a nodular structure which results from the growth of aggregates of anhedral globular to subhedral lenticular crystals which deform the host sediment. The mineral composition of the nongypsum intercalations is similar to that of the balatino-type gypsum: quartz, clays, feldspars, carbonates (mostly calcite), and occasionally pyrite. Biogenic layers, typical of "balatino" are lacking, but foraminifers are frequently observed in the intercrystalline voids.

The wavy laminated gypsum at Site 654 , although lacking algal relics, displays numerous similarities with the gypsified stromatolites described in the Messinian gypsum of Sicily and $\mathrm{Cy}$ prus (Nesteroff, 1973; Garrison et al., 1978; Rouchy and Pierre, 1979; Rouchy and Monty, 1981; Rouchy, 1982) which argues for the algal control of some wavy structures. Several modern evaporitic pools are the sites of formation of wavy laminated gypsum: Ras Muhammad Pool along Red Sea coast (Friedman et al., 198S), Hutt lagoon in Australia (Arakel, 1980), and solar ponds of Alicante in Spain (Rouchy, 1982; Orti Cabo et al., 1984). Gypsification of cyanobacterial mats by interstitial growth of lenticular crystals during subaerial exposure have also been described in other modern evaporitic environments, as in Sri Lanka (Gunatilaka, 1975) and Baja California lagoons (Pierre, 1982). In all these settings, the diagenetic growth of gypsum tends to induce micronodular structures as described in ODP Sites 653 and 654.

Formation of the wavy laminated gypsum results probably by a complex succession of depositional and diagenetic processes including periodic subaqueous precipitation of gypsum interrupted by algal coating or detrital inputs, diagenetic overgrowth of gypsum crystals by precipitation from interstitial brine, precipitation of lenticular gypsum in algal mats, and/or destruction of the mat structure by oxidation of organic matter. These multistaged events explain the various microstructures which range from nearly regularly laminated to hummocky or nodular.

The facies of crystalline selenite gypsum include small lenticular gypsum crystals of several millimeters, and large ( $>$ centimeter) fragments of crystals, embedded in marlstones. The small crystalline gypsum (e.g., 653B-26X-1, 118-120 cm) is composed by pieces of translucent crystals with curved faces; this lenticular habit as well as mud inclusions along the cleavage planes record the early diagenetic growth of gypsum into the muddy matrix. The main $(010)$ cleavage plane is affected by torsion structures, probably induced by localized stresses, possibly during crystal growth. This primary diagenetic facies results from displacive and/or enclosing growth from hypersaline pore waters within the host siltstone to marlstone sediment. No stromatolitic structures have been recognized, and gypsum precipitation might be related to the concentration of brines when the 
sediment was exposed during emersion stages. The large crystalline gypsum (e.g., 654A-31R-1, 124-126 cm) is composed of aggregates of crystals of various size with random to radial pattern. Small grains of carbonate and organic matter arranged in circular to oval bodies, are scattered in gypsum and suggest a relic organic framework replaced by gypsum; they might be either fecal pellets of brine shrimp as described in the Messinian gypsum of Sicily and at DSDP Site 378 (Schreiber, 1978; Garrison et al., 1978), or cross section of algal filaments as the gypsified stromatolites observed in the Messinian of Tuscany, Periadriatic area, Sicily and Cyprus (Vai and Ricci Lucchi, 1978,; Lo Cicero and Catalano, 1978; Rouchy and Monty, 1981; Rouchy, 1982). This facies may be assimilated to the classical selenite facies of primary and subaqueous precipitation at the basin floor; no indication of water depth may be deduced from its occurrence but the probable presence of algal filaments suggests shallow water deposition.

Reworked gypsum (gypsarenite, gypsrudite, gypsum breccia) is well developed at Hole 653B in Cores 27X and 28X. Schematically, three types of reworked grains of gypsum are observed and frequently associated in any layer; the first type corresponds to corroded cleavage fragments of various size with irregular shapes; in the second type, primary crystal morphologies (pinacoid heads, twinned and lenticular crystals), are preserved, thus precluding a very long transport. In both these two types, the reworked grains are enclosed in a composite matrix of carbonates, terrigenous components, and small gypsum grains. The third type is composed of aggregates of corroded gypsum fragments within a poorly developed matrix; these aggregates look similar to those produced by dissolution of oriented crystal crusts where the crystal shape is lost and produces the structure of gypsrudite with interlocking crystals (Schreiber, 1978; Geisler-Cussey, 1986). In a few samples (e.g., 653B-27X-4, 101-103 $\mathrm{cm}$ ) layers of reworked gypsum are associated with layers of euhedral lenticular gypsum grown in situ (Pl. 4, 1).

All these sedimentary structures reflect mechanical remobilization of gypsum, for which mechanisms of abrasion and transport have to be discussed. Accumulation of reworked gypsum is well-known in modern evaporitic environments (Vonder Haar, 1976; Arakel, 1980; Rouchy, 1982; Orti Cabo et al., 1984; Geisler-Cussey, 1986), as well as in fossil evaporites, in particular the Messinian of Mediterranean (Schreiber et al., 1976; Vai and Ricci Lucchi, 1978; Schreiber, 1978; Rouchy, 1982). In recent environments, reworking results from physical processes such as eolian deflation or aqueous destruction of exposed gypsum crusts. In fossil series, gypsrudites have been interpreted either as catastrophic debris flows (Schreiber et al., 1976) or as turbiditic deposits in deep basins originating from marginal gypsum sediments (Parea and Ricci Lucchi, 1972; Ricci Lucchi, 1973; Schreiber et al., 1976; Schlanger and Bolz, 1977). At Sites 653 and 654, structures rather suggest a short distance for transport of the gypsum elements and even in some cases in situ reworking.

The deformation of gypsum crystals cannot be considered as primary, but was rather caused by mechanical stresses (Pl. 4, 2). The breakage of crystals along cleavage planes may be produced by internal crystallogenetic processes such as the diagenetic growth within preexisting crystals (Schreiber, 1978; Arakel, 1980) and also by mechanical reworking. However, other features such as torsion and curvature of the cleavage planes (Pl. 4, 3), polysynthetic twinning, and undulatory extinction are most difficult to explain in absence of tectonic stress.

The presence of anhydrite relics within the reworked gypsum crystals is difficult to interpret because anhydrite may have been precipitated simultaneously with gypsum under special physicochemical conditions or it may represent the dehydration product of exposed gypsum crystals in hot and arid climatic conditions.
Unusual crystal habits of microspherulitic gypsum associated with anhydrite are observed in several samples at Site 653 (e.g., in the levels: 653B-27X-4, 101-103 cm; 653B-28X-1, 120$122 \mathrm{~cm}$; 653B-28X-2, 49-51 cm; 653B-28X-2, 70-72 cm). Hand specimens are characterized by their white color and their more or less granular aspect. Analyses by $\mathrm{x}$-ray diffraction indicate the presence of anhydrite which may form pure intercalations in a few samples. The common fabric observed in thin sections consists in the development of fibrous and microspherulitic structures (Pl. 4, 4-6).

The simplest fibrous structure (e.g., 653B-27X-4, 101-103 cm) appears in the parallel and subvertical gypsum crystals which are invaded by fibers arranged in alignment or in clusters; this replacement progresses upward from the top of the layer and from the intracrystalline boundaries (PI. 4, 4). Transitional stages between fibrous and spherulitic structures are observed in the samples of gypsarenite (e.g., 653B-27X-CC, 34-36 cm, and 653B$28 \mathrm{X}-2,120-122 \mathrm{~cm}$ ), where reworked crystals are either partially or totally invaded by a mosaic of fibers, or coated by radial fibrous gypsum giving structures that evoke gypsum ooids (Pl. 4, 5). However, these structures differ from the gypsum oolites described in the Messinian of Sicily by Ciaranfi et al. (1978); the composite coating and the layered orientation of some fibrous rims are considered as the result of in situ concretionary growth. The lack of cement between the spheroidal bodies suggest formation by dissolution-recrystallization processes.

The spherulitic structure has been observed in the upper part of a gypsarenite sequence, below an erosional surface overlain by another gypsarenite layer. It consists of an imbrication of clusters, as much as $500 \mu \mathrm{m}$ in diameter, of gypsum laths radiating from a nucleus of tiny gypsum crystals, clays, and carbonates $(\mathrm{Pl} .4,6)$. The largest prisms of gypsum are projected into the voids between the spherulites. The spherulitic aggregates are generally devoid of cement.

Syndepositional or burial dehydration of gypsum may explain both these fibrous structures. Syndepositional alteration is well documented in modern evaporitic environments where gypsum crystals exposed to hot and arid conditions and/or to changing brine chemistry, are replaced by bassanite and anhydrite (Moiola and Glover, 1965; Butler, 1970; Pierre, 1982; Shearman, 1983; Rouchy et al., 1986). In Clayton playa (Nevada), the surficial alteration of lenticular gypsum crystals consists of a double coating of white and fibrous material composed by an outer anhydrite rim and an inner bassanite rim (Moiola and Glover, 1965). At Site 653 , fibrous gypsum might be produced by rehydration of this type of material because altered parts occur mostly around the crystals; anhydrite might be relic of this transformation. Burial would also cause gypsum dehydration if temperature and pore water salinity required for this transformation are reached (MacDonald, 1953; Blount and Dickson, 1973; Hardie, 1967). However, salinity of $45 \mathrm{~g} / \mathrm{L}$ and temperature of about $25^{\circ} \mathrm{C}$ measured at $250 \mathrm{~m}$ of burial depth at Site 653 (Kastens, Mascle, et al., 1987) were too low to produce the transformation of gypsum to anhydrite.

\section{Stable Isotopes}

The oxygen and sulfur isotope compositions of sulfate minerals precipitated from normal seawater have been almost constant throughout the Cenozoic, indicating homogeneity of the global reservoir of oceanic aqueous sulfate through time and space during this period (Claypool et al., 1980). However, studies on modern marine evaporites have shown that bacterial redox processes, as well as crystallization-dissolution processes, may induce large isotopic variations in the aqueous and solid sulfate phases (Pierre, 1982, 1985, 1987, 1988; 1989; Pierre and Fontes, 1982; Pierre et al., 1984b). Evidencing such $\delta$ variations in gypsum/anhydrite deposits is of the greatest interest for pa- 
leoenvironmental reconstructions because they mean that the local pool of marine aqueous sulfate might be no more homogeneous due to the intervention of these organic and inorganic effects.

Previous isotopic data on Messinian sulfate evaporites from other Mediterranean occurrences had already revealed the large variability of sulfate $\delta$ values and related it to bacterial and inorganic processes (Fontes et al., 1973a, b; Pierre, 1974, 1982; Pierre and Fontes, 1978, 1979; Ricchiutto and McKenzie, 1978; Rouchy and Pierre, 1979). Similarly, the $\delta$ values of gypsum samples from Sites 653 and 654 (Table 1) cover a wide range $\left(+13.1<\delta^{18} \mathrm{O}<+20.3 ;+18.3<\delta^{34} \mathrm{~S}<+23.4\right)$ which overlaps the $\delta$ values measured on present-day gypsum of various facies (selenitic crusts, lenticular crystals) from marine salt pans (Fig. 2). These results clearly demonstrate the marine origin of the sulfate from which are derived the gypsum deposits from Sites 653 and 654 . The general $\delta^{18} \mathrm{O}-\delta^{34} \mathrm{~S}$ relationship in gypsum of various facies indicates that organic and inorganic effects have both acted in the sedimentary or early diagenetic environment to produce either enrichment or depletion in $\delta^{18} \mathrm{O}$ and ${ }^{34} \mathrm{~S}$ relative to the original source of marine sulfate.

The highest $\delta^{18} \mathrm{O}$ values $(+17.7$ to +20.3$)$ and $\delta^{34} \mathrm{~S}$ values $(+22.1$ to +23.4$)$ are measured at Site 654 in the laminated gypsum; they are indicative that during deposition of gypsum, the intense activity of sulfate-reducing bacteria resulted in an increase of both oxygen and sulfur isotope ratios of the remaining aqueous sulfate. These conclusions are supported by SEM observations which have revealed the abundance of bacteria trapped within the gypsum crystals (Pl. 1, 4; Pl. 2, 1-3).

The lowest $\delta^{34} \mathrm{~S}$ values $(+18.3$ to +20.4$)$, associated with variable $\delta^{18} \mathrm{O}$ values $(+13.7$ to +19.3$)$, are measured at both Sites 653 and 654 in millimeter- to centimeter-size gypsum crystals embedded in marlstones. Such gypsum facies are commonly generated at or below the water-sediment boundary where reducing conditions generally prevail and favor the production of hydrogen sulfide by anaerobic bacteria. The decrease of $\delta^{34} \mathrm{~S}$ values is therefore interpreted partly as the result of the variable contribution of a sulfate component coming from the reoxidation of reduced sulfur in waters of variable $\delta^{18} \mathrm{O}$ values (i.e., of variable concentrations related to evaporation/dilution effects).

Furthermore, it is also highly probable that the simultaneous decrease of $\delta^{18} \mathrm{O}-\delta^{34} \mathrm{~S}$ values of sulfate minerals reflects to some extent the intervention of a "reservoir effect"; this would mean that the input rate of aqueous sulfate might be lower than the output rate of sulfate due to massive gypsum precipitation in the basin.

\section{Carbonates}

\section{Petrography and Mineralogy}

Carbonate levels from Sites 653 and 654 include the sediments intercalated with the gypsum layers at both sites and the infra-gypsum layers at Site 654. In the gypsum sequence, calcite is the major component of the carbonate fraction, but dolomite may be associated with calcite at a few levels or constitute an exclusive component. The $d_{104}$ value of calcite is rather constant (3.033-3.037 $\AA$ ) and indicates a low-Mg composition. SEM examinations of calcite-rich samples show small (less than $10 \mu \mathrm{m}$ ) euhedral crystals or irregular grains; small perforations at their surface might be due to dissolution processes (Pl. 5, 1). A few crystals present internal voids related to growth lacunas rather than dissolution holes (Pl. 5, 1). Dolomites are calcium-rich with a compositional range of $\mathrm{Ca}_{54} \mathrm{Mg}_{46}-\mathrm{Ca}_{52} \mathrm{Mg}_{48}$; in the Sample $653 \mathrm{~B}-27 \mathrm{X}-3,106-108 \mathrm{~cm}$, where dolomite is the exclusive carbonate component, the crystals appear as small $(<10 \mu \mathrm{m})$ euhedral rhombohedra.
The lowermost Messinian sediments from Site 654 are represented by dark and finely laminated dolomitic claystones rich in organic matter and locally in pyrite; these characteristics and the presence of biogenic remains of radiolarians, diatoms, sponge spicules, fish teeth, and scales lead to consideration of this interval as an equivalent of the Tripoli Formation of Sicily (Kastens, Mascle, et al., 1987). The observation of pure diatomitic laminae (Pl. 5, 2-3) composed by the dominant genus Thalassionema probably associated with Thalassiothrix at one level supports the correlation with the preevaporitic laminites of the Mediterranean basin (McKenzie et al., 1979; Rouchy, 1982). Dolomite with a composition of $\mathrm{Ca}_{54} \mathrm{Mg}_{46}-\mathrm{Ca}_{56} \mathrm{Mg}_{44}$ is the exclusive component of the carbonate fraction. Crystal habits of the dolomite are of two types; the most common form corresponds to round grains of $6 \mu \mathrm{m}$ of average diameter (PI. 5, 2 and 4) which is very similar in shape and size to that described in the supratidal evaporite flats of Ojo de Liebre lagoon in Baja California (Pierre, 1982; Pierre et al., 1984a); the second type of dolomite is represented by euhedral rhombs less than $10 \mu \mathrm{m}$ in size.

\section{Stable Isotopes}

The carbonate samples from Sites 653 and 654 were selected for stable isotope analysis throughout the cored Messinian intervals. They come from marly to silty sediments in which gypsum crystals are embedded or form layers intercalated between the gypsum beds, and from the grey dolomitic marlstone of the lowermost Messinian. Isotopic compositions of these carbonates are considered to have registered the overall ambient parameters acting in the Tyrrhenian area during the Messinian. The $\delta$ values of calcites and dolomites will be discussed separately (Fig. 3, Tables 2, 3) owing to the different paths of oxygen and carbon isotope fractionation which occur during crystallization of these minerals (Northrop and Clayton, 1966; Fritz and Smith, 1970; Sheppard and Schwarcz, 1970; Matthews and Katz, 1977).

\section{Calcites}

From a general point of view, the $\delta$ values of calcites exhibit large ranges of variations $\left(-6.67<\delta^{18} \mathrm{O}<+0.23 ;-3.62<\right.$ $\delta^{13} \mathrm{C}<+1.85$ ) which are indicative of highly and rapidly changing geochemical conditions (water salinity, i.e., evaporation/dilution mass-balance; temperature; $\Sigma \mathrm{CO}_{2}$ ) throughout Messinian times. Huge dilution of marine waters by continental inputs into the basin is emphasized by the lowest $\delta^{18} \mathrm{O}$ values of calcite; these events occurred variously during Messinian, even at the time of gypsum deposition during precipitation of the carbonate partings of the laminated and selenitic gypsum. As stated earlier from isotope data from other Messinian occurrences (Fontes et al., 1973a, b; Pierre, 1974, 1982; Pierre and Fontes, $1978,1979)$, such drastic fluctuations from brackish to hypersaline conditions required very shallow-water deposition and eventual exposure episodes.

The $\mathrm{\Sigma CO}_{2}$ reservoir of waters might be either close to equilibrium with atmospheric $\mathrm{CO}_{2}\left(\delta^{13} \mathrm{C}\right.$ calcite $\left.>0\right)$ when wellmixed conditions were extant in the basin, or contaminated with oxidation products of organic matter (of terrestrial or marine origin) to account for the lowest $\delta^{13} \mathrm{C}$ values of calcites. In summary, Messinian calcites from Sites 653 and 654 have been deposited in rather open and oxidized conditions. Organic matter was not preserved within the sediment because it was probably largely used for sulfate-reducing bacterial activity.

\section{Dolomites}

The ranges of $\delta$ values of dolomites $\left(-1.18<\delta^{18} \mathrm{O}<+6.63\right.$; $-2.78<\delta^{13} \mathrm{C}<+1.29$ ) are of the same order as for calcites, as expected for minerals deposited in similar environmental conditions. In this sense, calcites and dolomites appear cogenetic; 
Table 1. Simplified lithological description and stable isotope compositions of sulfates at ODP Sites 652,653 , and 654 .

\begin{tabular}{|c|c|c|c|c|}
\hline $\begin{array}{l}\text { Core, section, } \\
\text { interval }(\mathrm{cm})\end{array}$ & $\begin{array}{l}\text { Depth } \\
\text { (mbsf) }\end{array}$ & Lithological description & $\begin{array}{c}\delta^{18} \mathrm{O} \\
\text { SMOW }\end{array}$ & $\begin{array}{l}\delta^{34} \mathrm{~S} \\
\mathrm{CDT}\end{array}$ \\
\hline \multicolumn{5}{|l|}{ 107-653B- } \\
\hline $25 \mathrm{X}-1,7-10$ & 225.77 & Wavy-laminated gypsum & 15.4 & 21.0 \\
\hline $25 \mathrm{X}-1,52-54$ & 226.22 & Gypsum crystals in calcareous siltstone & 15.8 & 21.3 \\
\hline $25 X-1,68-70$ & 226.38 & Regular-laminated gypsum & 15.8 & 21.1 \\
\hline $26 \mathrm{X}-1,52-54$ & 235.72 & Regular-laminated gypsum & 13.9 & 19.3 \\
\hline $26 \mathrm{X}-1,118-120$ & 236.48 & Crystalline gypsum (selenite to macrolenticular) & 14.2 & 18.9 \\
\hline $26 \mathrm{X}-2,28-30$ & 237.08 & Lenticular gypsum in calcareous siltstone & 14.2 & 19.4 \\
\hline $27 X-1,57-59$ & 245.47 & Lenticular gypsum in calcareo-dolomitic siltstone & 13.7 & 20.4 \\
\hline $27 X-4,101-103$ & 250.41 & Gypsarenite and lenticular crystals in varicolored siltstone & & \\
\hline $27 \mathrm{X}-\mathrm{CC}(34-36)$ & 254.60 & Gypsum and anhydrite in ochre siltstone & & \\
\hline $28 \mathrm{X}-1,120-122$ & 255.80 & Gypsarenite with fibrous alteration and microspherultic facies & & \\
\hline $28 X-1,134-136$ & 255.94 & Gypsarenitic layers in dark claystone & & \\
\hline $28 \mathrm{X}-2,49-51$ & 256.59 & Gypsarenitic layers in siltstone ( + anhydrite) & 17.1 & 19.8 \\
\hline $28 X-2,88-90$ & 256.82 & Nodular gypsum (+ anhydrite), gypsarenite and anhydrite: & 18.8 & 21.3 \\
\hline & & microspherulitic facies in dark siltstone gypsum & 18.5 & 22.0 \\
\hline \multicolumn{5}{|l|}{$107-654 \mathrm{~A}-$} \\
\hline $27 \mathrm{R}-1,30-33$ & 242.70 & Regular-laminated gypsum & 18.1 & 22.4 \\
\hline $28 \mathrm{R}-1,14-17$ & 252.14 & Regular- and wavy-laminated gypsum & 17.7 & 22.4 \\
\hline $28 \mathrm{R}-1,64-67$ & 252.64 & Wavy-laminated gypsum & 18.3 & 22.1 \\
\hline $28 \mathrm{R}-2,43-45$ & 253.93 & Crystalline gypsum (selenite) in varicolored siltstone & & \\
\hline $28 \mathrm{R}-\mathrm{CC}(1-3)$ & 261.70 & Laminated gypsum & 19.3 & 20.3 \\
\hline $29 R-2,6-8$ & 263.26 & White gypsum in varicolored calcareo-dolomitic siltstone & 18.1 & 22.9 \\
\hline $29 \mathrm{R}-2,16-18$ & 263.36 & Regular-laminated gypsum & 20.3 & 22.9 \\
\hline $29 \mathrm{R}-2,132-134$ & 264.52 & Selenitic to lenticular gypsum in calcareo-dolomitic claystone & & \\
\hline $30 \mathrm{R}-1,88-90$ & 272.18 & Regular-laminated gypsum & 18.2 & 22.1 \\
\hline $30 \mathrm{R}-1,134-136$ & 272.64 & Wavy-laminated gypsum & 18.3 & 22.1 \\
\hline $31 \mathrm{R}-1,104-106$ & 277.34 & Crystalline gypsum & 17.6 & 20.6 \\
\hline $31 \mathrm{R}-1,139-141$ & 277.69 & Regular-laminated gypsum & 18.0 & 22.1 \\
\hline $32 \mathrm{R}-1,132-135$ & 282.22 & Regular-laminated gypsum & 18.7 & 22.2 \\
\hline $32 \mathrm{R}-2,40-43$ & 282.80 & Regular-laminated gypsum & 18.8 & 22.1 \\
\hline $32 \mathrm{R}-\mathrm{CC}(19-21)$ & 287.60 & Wavy-laminated gypsum & 19.4 & 22.7 \\
\hline $33 \mathrm{R}-1,66-68$ & 288.26 & Crystalline (selenite) gypsum & 18.1 & 23.1 \\
\hline $33 \mathrm{R}-1,80-82$ & 288.40 & Regular-laminated gypsum & 17.8 & 21.3 \\
\hline $33 \mathrm{R}-1,89-91$ & 288.49 & Wavy-laminated gypsum & 18.0 & 21.1 \\
\hline $34 \mathrm{R}-1,11-13$ & 290.71 & Saccharoidal gypsum & 18.3 & 22.9 \\
\hline $34 \mathrm{R}-4,33-34$ & 295.43 & Regular-laminated gypsum & 18.0 & 23.4 \\
\hline $35 \mathrm{R}-\mathrm{CC}(7-9)$ & 310.00 & Regular-laminated gypsum & 15.1 & 22.3 \\
\hline \multicolumn{5}{|l|}{ 107-652A- } \\
\hline $35 \mathrm{R}-1,36-38$ & 325.36 & $\begin{array}{l}\text { Small anhydrite nodules }(+ \text { gypsum) in calcareous (and } \\
\text { dolomitic) siltstone to sandstone }\end{array}$ & & \\
\hline $37 \mathrm{R}-4,36-39$ & 349.16 & $\begin{array}{l}\text { Layer of small nodules of anhydrite ( }+ \text { gypsum) in calcare- } \\
\text { ous varicoloured (and dolomitic) siltstone }\end{array}$ & & \\
\hline $37 R-4,74-75$ & 349.54 & $\begin{array}{l}\text { Scattered anhydrite (+ gypsum) nodules in laminated silt- } \\
\text { stone }\end{array}$ & 14.0 & 19.8 \\
\hline $37 \mathrm{R}-5,54-56$ & 350.84 & Nodules of anhydrite (+ gypsum) & 15.0 & 19.9 \\
\hline $37 R-5,92-95$ & 351.22 & $\begin{array}{l}\text { Small nodules of anhydrite ( }+ \text { gypsum) in calcareous silt- } \\
\text { stone }\end{array}$ & 14.3 & 20.1 \\
\hline $38 \mathrm{R}-3,8-10$ & 357.08 & Nodular to mosaic anhydrite ( + gypsum) & 17.5 & 24.5 \\
\hline $38 \mathrm{R}-3,41-43$ & 357.41 & Nodular anhydrite (+ gypsum) & 16.5 & 20.7 \\
\hline $43 \mathrm{R}-5,109-111$ & 409.49 & Layered nodular anhydrite in grey marlstone & 17.1 & 21.2 \\
\hline $44 \mathrm{R}-3,59-62$ & 415.69 & Nodular to mosaic anhydrite $(+$ gypsum $)$ & 17.1 & 21.8 \\
\hline $61 \mathrm{R}-4,36-38$ & 580.46 & Anhydritic ( + gypsum) laminae in grey dolomitic siltstone & & \\
\hline $64 \mathrm{R}-2,41-43$ & 606.41 & Anhydrite in dolomitic siltstone & & \\
\hline $65 \mathrm{R}-1,30-33$ & 614.50 & Anhydrite in dolomitic siltstone & & \\
\hline $69 \mathrm{R}-1,120-121$ & 654.60 & Anhydrite $(+$ gypsum) interbeds in dolomitic siltstone & & \\
\hline $70 \mathrm{R}-4,79-81$ & 668.39 & Anhydrite in dolomitic siltstone & & \\
\hline $70 R-4,126-128$ & 668.86 & $\mathrm{Cm}$ layer of anhydrite in dolomitic siltstone & & \\
\hline $71 \mathrm{R}-1,15-18$ & 672.95 & Anhydritic laminae in calcareo-dolomitic siltstone & & \\
\hline
\end{tabular}

this is also evidenced in the dolomite-calcite assemblages where the measured difference $\left(+3.0\right.$ to $+4.5 \%$ ) between the $\delta^{18} \mathrm{O}$ values of dolomite and calcite corresponds to the experimental value of the oxygen isotope fractionation factor at low temperatures between dolomite and calcite (Fritz and Smith, 1970; Matthews and Katz, 1977).

The highest $\delta^{18} \mathrm{O}$ values are measured in the dolomites from the lowermost Messinian deposits; they are among the highest ones reported for Messinian dolomites in the lower Messinian Tripoli formation of Sicily (Pierre, 1974, 1982; Pierre and Fontes,
1979; McKenzie et al., 1979). Both are indicative of the high degree of evaporation in the waters where crystallization occurred. However, redox conditions which are related to the amounts of organic matter available were drastically different at these two sites: reducing conditions and intense bacterial activity were prevalent in the organic-rich sediments of Sicily and explain the very low $\delta^{13} \mathrm{C}$ values (down to $-30 \%$ ) of dolomites; low organic productivity at the Tyrrhenian Site 654 maintained oxidizing conditions in the organic-poor sediments that account for the moderately low $\delta^{13} \mathrm{C}$ values $(-2.8 \%$ to $-1.7 \%$ ) of dolomites. 


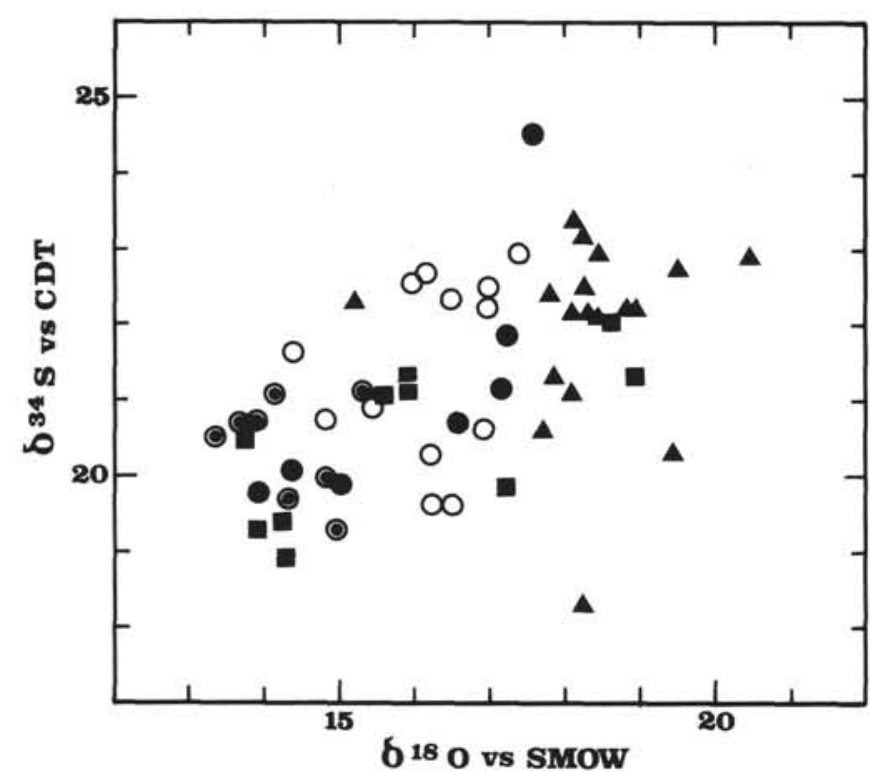

\begin{tabular}{|ll|}
\hline $652 \quad 653$ & a 654 \\
0 & Mormona lagoon \\
\hline & Marine salt pans
\end{tabular}

Figure 2. Oxygen and sulfur isotope compositions of gypsum-anhydrite samples from ODP Holes $652 \mathrm{~A}, 653 \mathrm{~B}$, and $654 \mathrm{~A}$. Isotope data for present-day gypsum collected in Mediterranean salt pans (Pierre and Fontes, 1979; Pierre, 1982; Pierre et al., 1984 b) and in Mormona Lagoon in Baja California (Pierre, 1982) are reported for comparison.

\section{Site 652}

The pre-Pliocene sequence of azoic sediments is separated from the Pliocene-Pleistocene hemipelagic deposits by a $40-\mathrm{cm}-$ thick transition zone of varicolored (brown, red, gray, greenish) clays and mudstones which would indicate subaerial weathering of the adjacent land areas (Kastens, Mascle, et al., 1987). A similar transitional interval has been described in the uppermost Messinian of Cyprus in which the red color results from the weathering of underlying Messinian paleosols (Rouchy et al., 1980; Rouchy, 1982). The underlying sedimentary succession attributed to the Messinian is rather homogeneous and consists mostly of medium to dark gray thinly bedded mudstones, claystones, siltstones, and sandstones, interpreted as turbidites in the upper part of the section, where six to seven gypsum/anhydrite-rich levels are present. At $335 \mathrm{~m}$ sub-bottom depth, a 10-mthick layer of rounded pebbles (sedimentary and metamorphic rocks originating from the Appenines and Sicily) marks a main detrital (fluvial?) discharge into the basin. The series recovered at Site 652 differs largely from other deep sea series as well as outcropping formations of Messinian age, by the thinness of the disseminated evaporitic intercalations and the lack of sequential organization despite their apparent cyclicity (Kastens, Mascle, et al., 1987).

At this site, heat flow measurements give a geothermal gradient of $14^{\circ} \mathrm{C} / 100 \mathrm{~m}$ in the upper $36 \mathrm{~m}$ which lowers to $10.5^{\circ} \mathrm{C} /$ $100 \mathrm{~m}$ below $150 \mathrm{~m}$; in-situ temperatures increase thus downward from about $40^{\circ} \mathrm{C}$ to $110^{\circ} \mathrm{C}$ for the entire 530 -m section of pre-Pliocene sediments. Diagenetic thermal effects are thus expected to have induced recrystallization of sulfate and carbonate phases in the sedimentary sequence.

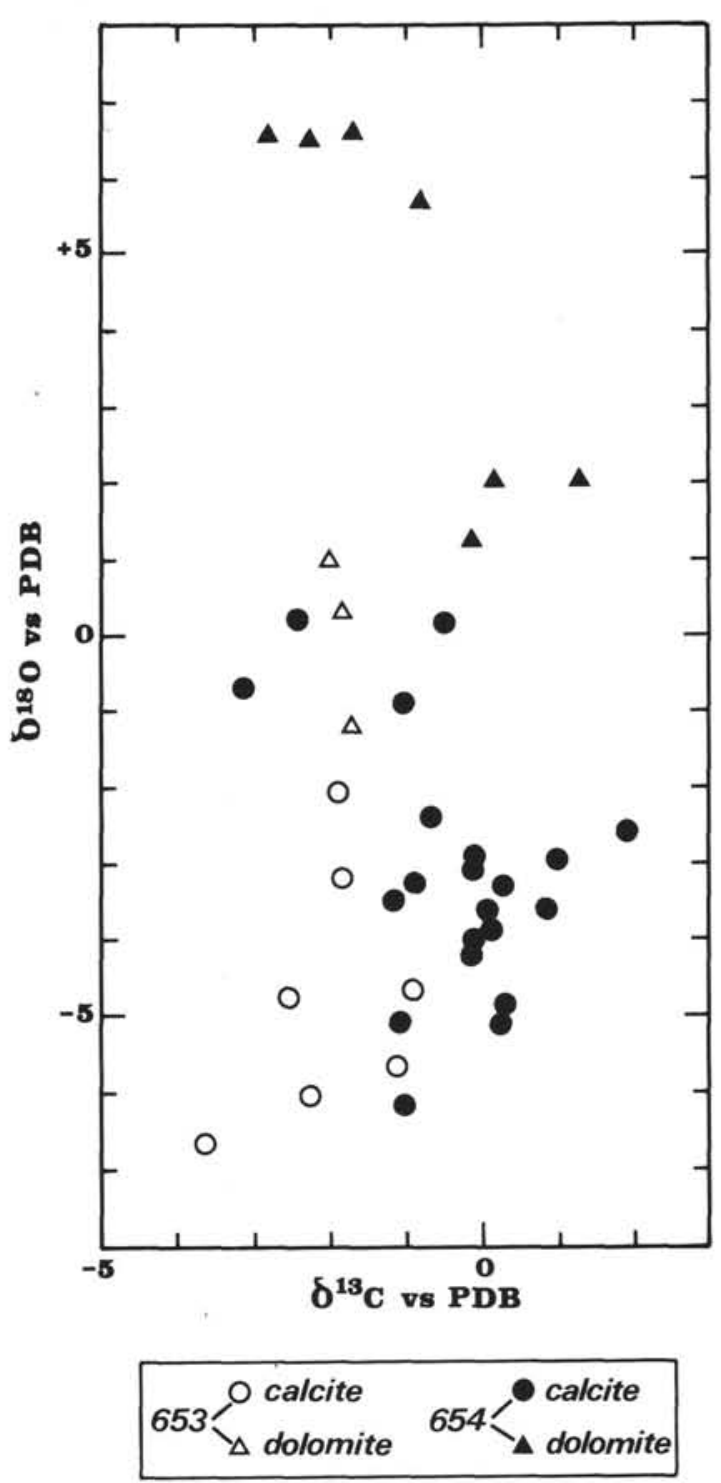

Figure 3. Oxygen and carbon isotope compositions of carbonates from ODP Holes 653B and 654A.

Table 2. Stable isotope compositions of carbonates at ODP Hole 653B. The $\delta^{18} \mathrm{O}$ values of dolomites are corrected by $-0.8 \%$ for the oxygen isotope fractionation effect that occurs during phosphoric acid extraction (Sharma and Clayton, 1965).

\begin{tabular}{lccccc}
\hline $\begin{array}{c}\text { Core, section, } \\
\text { interval }(\mathrm{cm})\end{array}$ & $\begin{array}{c}\text { Depth } \\
\text { (mbsf) }\end{array}$ & $\begin{array}{c}\delta^{18} \mathrm{O} \\
\text { calcite }\end{array}$ & $\begin{array}{c}\delta^{13} \mathrm{C} \\
\text { calcite }\end{array}$ & $\begin{array}{c}\delta^{18} \mathrm{O} \\
\text { dolomite }\end{array}$ & $\begin{array}{c}\delta^{13} \mathrm{C} \\
\text { dolomite }\end{array}$ \\
\hline $107-653 \mathrm{~B}-$ & & & & & \\
& & & & & \\
$26 \mathrm{X}-1,52-54$ & 235.82 & -4.73 & -2.44 & & \\
$26 \mathrm{X}-1,118-120$ & 236.48 & -6.67 & -3.62 & & \\
$26 \mathrm{X}-2,28-30$ & 237.08 & -3.08 & -1.87 & & \\
$26 \mathrm{X}-2,50-52$ & 237.30 & -2.17 & -1.91 & & \\
$27 \mathrm{X}-1,57-59$ & 245.47 & -5.65 & -1.05 & -1.18 & -1.68 \\
$27 \mathrm{X}-3,106-108$ & 248.96 & & & +0.17 & -1.98 \\
$27 \mathrm{X}-3,148-150$ & 249.38 & & & -0.47 & -1.84 \\
$27 \mathrm{X}-4,42-44$ & 249.82 & & & \\
$27 \mathrm{X}-4,138-140$ & 250.78 & -6.00 & -2.21 & & \\
$27 \mathrm{X}-\mathrm{CC},(8-10)$ & 254.25 & -4.59 & -0.89 & & \\
& & & & &
\end{tabular}


Table 3. Stable isotope compositions of carbonates at ODP Hole $654 \mathrm{~A}$. The $\delta^{18} \mathrm{O}$ values of dolomites are corrected by $-0.8 \%$ for the oxygen isotope fractionation effect that occurs during phosphoric acid extraction (Sharma and Clayton, 1965).

\begin{tabular}{|c|c|c|c|c|c|}
\hline $\begin{array}{l}\text { Core, section, } \\
\text { interval }(\mathrm{cm})\end{array}$ & $\begin{array}{l}\text { Depth } \\
\text { (mbsf) }\end{array}$ & $\begin{array}{c}\delta^{18} \mathrm{O} \\
\text { calcite }\end{array}$ & $\begin{array}{l}\delta^{13} \mathrm{C} \\
\text { calcite }\end{array}$ & $\begin{array}{c}\delta^{18} \mathrm{O} \\
\text { dolomite }\end{array}$ & $\begin{array}{c}\delta^{13} \mathrm{C} \\
\text { dolomite }\end{array}$ \\
\hline \multicolumn{6}{|l|}{$107-654 \mathrm{~B}-$} \\
\hline $28 R-1,64-66$ & 252.64 & -3.57 & +0.05 & & \\
\hline $28 \mathrm{R}-1,133-137$ & 253.33 & -2.96 & +0.96 & & \\
\hline $28 \mathrm{R}-2,10-13$ & 253.60 & -2.65 & +1.85 & & \\
\hline $28 \mathrm{R}-2,43-45$ & 253.93 & +0.23 & -2.41 & & \\
\hline $28 \mathrm{R}-2,75-79$ & 254.25 & -3.73 & 0.12 & & - \\
\hline $28 \mathrm{R}-3,50-52$ & 255.50 & +0.17 & -0.45 & +1.23 & -0.11 \\
\hline $28 \mathrm{R}-4,30-32$ & 256.80 & -0.71 & -3.11 & & \\
\hline 28R-CC, (1-3) & 262.50 & -5.06 & -1.06 & & \\
\hline $29 \mathrm{R}-1,117-119$ & 262.87 & & & +5.75 & -0.80 \\
\hline $29 R-2,6-8$ & 263.26 & -0.92 & -0.99 & +2.11 & +1.29 \\
\hline $29 \mathrm{R}-3,19-21$ & 264.89 & -2.39 & -0.66 & +2.12 & +0.15 \\
\hline $30 \mathrm{R}-1,30-32$ & 271.60 & -3.52 & -1.17 & & \\
\hline $31 \mathrm{R}-1,65-67$ & 276.95 & -4.02 & -0.07 & & \\
\hline $31 \mathrm{R}-1,104-106$ & 277.34 & -4.20 & -0.13 & & \\
\hline $32 \mathrm{R}-1,119-121$ & 282.09 & -5.12 & +0.23 & & \\
\hline $33 \mathrm{R}-1,89-91$ & 288.49 & -3.25 & -0.92 & & \\
\hline $33 \mathrm{R}-1,134-137$ & 288.94 & -3.62 & +0.87 & & \\
\hline $35 \mathrm{R}-1,81-85$ & 301.11 & -2.86 & -0.07 & & \\
\hline $35 R-1,131-133$ & 301.61 & -3.31 & +0.29 & & \\
\hline $38 \mathrm{R}-1,77-79$ & 330.07 & -3.02 & -0.05 & & \\
\hline $39 \mathrm{R}-2,78-79$ & 340.88 & & & +6.55 & -2.78 \\
\hline $39 \mathrm{R}-2,137-138$ & 341.47 & & & +6.63 & -1.71 \\
\hline $39 \mathrm{R}-3,1-2$ & 341.61 & & & +6.52 & -2.25 \\
\hline
\end{tabular}

\section{Sulfates}

\section{Petrography and Mineralogy}

The thickness and lithofacies of evaporites at Site 652 differ significantly from those described at Sites 653 and 654 . Gypsum sands are frequently intercalated in the uppermost sediments. From about $315 \mathrm{~m}$ (Core 34R) to the bottom of the hole, anhydrite is the major component, but gypsum is always present in minor amounts down to $670 \mathrm{~m}$ (Core 73R) as mentioned in the core description (Kastens, Mascle, et al. 1987). The evaporiterich intervals consist of a succession of centimeter-thick layers of anhydrite within a silty matrix, except some levels in Core $44 \mathrm{R}$ where more massive sulfate beds reach several decimeters in thickness. The most characteristic features of these thin beds are: (1) the pseudonodular to nodular facies of anhydrite, (2) the sharp limits between anhydrite and the embedding sediment, and (3) the breakup of some layers and the relative displacement of anhydrite fragments.

The facies of nodular anhydrite includes several morphostructural types (Pl. 6, 1 and 2; Pl. 7, 1). Centimeter-thick layers of nodular anhydrite show subvertical orientation of nodules (e.g., $652 \mathrm{~A}-38 \mathrm{R}-3,8-10 \mathrm{~cm}$ ). The upper boundaries of nodules display angular forms typical of the terminations of former gypsum crystals; other pseudomorphs of anhydrite after isolated and randomly-oriented gypsum crystals occur in the overlying silty sediment. Fine laths of anhydrite are preferentially oriented in a subvertical way with a radial pattern. All these structures indicate the transformation of primary gypsum aggregates which were originally oriented selenitic crusts rather than fibrous gypsum. A few layers exhibit sharp upper and lower boundaries that suggest replacement of fibrous satin-spar gypsum.

Layers of nodular anhydrite (e.g., 652A-37R-4, 74-75 cm) differ from the preceding by lacking obvious relics of crystalline precursors (PI. 6, 1 and 2).

In the laminated anhydrite (e.g., 652A-44R-3, 59-62 cm), 2 -mm-thick anhydrite laminae alternate with dolomite laminae of 0.4-1 mm in thickness (Pl. 6, 2). As in the "balatino" type of gypsum, a second-order lamination of $0.3-0.7 \mathrm{~mm}$ of thickness is emphasized by carbonate particles and cross-bedding. Anhydrite laminae are composed of aggregates of laths as long as $0.5 \mathrm{~mm}$ in length. The external boundaries of these aggregates or clusters represent obvious ghosts of former gypsum crystals, some of them lie isolated within dark carbonate intercalations (PI. 7, 1). The laminated anhydrite is associated with isolated to coalescent nodules of millimeter to centimeter size; a few have a rounded shape whereas others more or less angular suggest that part of these nodules were initially gypsum crystals, crystalline aggregates, or gypsum clasts. Subvertical orientation of these nodules might be that of selenitic crusts growing upon the laminated gypsum. Deformation of the host sediment around nodules (e.g., 652A-44R-3, 76-77 cm) seems to indicate an in-situ displacive growth, sometimes multistaged, of these nodules modifying the former laminated morphology of sulfate (e.g., 652A38R-3, 74-76 cm).

Typical anhydritized gypsarenite and scattered gypsum clasts are associated with thin layers of laths of anhydrite. In a few levels (e.g., 652A-38R-3, 110-115 cm), scattered millimeter- to centimeter-size nodules seem to be reworked fragments from broken nodular beds or crystalline gypsum.

Lenticular crystals of $2-3 \mathrm{~mm}$ in length are abundant at the level $652 \mathrm{~A}-35 \mathrm{R}-1,36-42 \mathrm{~cm}$; cross-bedding of the silty host sediment seems to have controlled the in-situ growth of gypsum within the host sediment enclosed in the crystals as particles of quartz, zoned rhombs of dolomite, and reworked foraminifers. Dispersed lenticular gypsum is also identified in anhydrite layers (652A-71R-1, 15-18 cm), and anhydrite blebs at the level $652 \mathrm{~A}-70 \mathrm{R}-3,7-10 \mathrm{~cm}$, might be pseudomorphosed lenticular gypsum. In the lower part of the series (e.g., 652A-61R-4, 36-38 $\mathrm{cm}$ ), millimeter-thick indurated laminae are composed by a mixture of dolomite and anhydrite; aggregates of laths of anhydrite are located either around euhedral to subhedral dolomite crystals, or in the intercrystalline voids.

The preservation of various gypsum morphologies in the associated gypsum indicates its secondary origin. The facies of gypsum associated with anhydrite nodules is that of lenticular or prismatic euhedral to subhedral crystals, which size varies from $80 \mu \mathrm{m}$ to $500 \mu \mathrm{m}$; twinned forms are observed and a few crystals present rectangular boundaries which suggest replacement of former anhydrite. The crystals have grown isolated or grouped in aggregates. Concentration and growth of such crystals are obviously related to the presence of nearby anhydrite nodules which deform the host sediment. The imbricated crystals develop as an outer rim of the nodules or invade them from the internodular boundaries (Pl. 7, 2). They are frequently subperpendicular to the upper surface of the nodules and make upward-diverging clusters. At the level $652 \mathrm{~A}-38 \mathrm{R}-3,41-43 \mathrm{~cm}$, aggregates of small $(<50 \mu \mathrm{m})$ lenticular crystals cross the nodular layer and form irregular concentric bands in the overlying sediment, so that anhydrite nodules take a residual aspect.

Relationships between anhydrite and gypsum are very ambiguous; most gypsum crystals enclose anhydrite either as scattered inclusions or as rounded aggregates even when they are developed in the host sediment which is disturbed around them (Pl. 7, 3). These structural relations might indicate either incomplete gypsum-anhydrite transformation, or the late development of gypsum after former anhydrite nodules. However, petrographic observations suggest that gypsum was mostly derived from rehydration of anhydrite, although in some cases anhydrite was secondary after gypsum.

From paleoenvironmental considerations, layered gypsumanhydrite facies were probably generated by direct subaqueous precipitation from brines at the basin floor, while other facies (lenticular gypsum, anhydrite nodules deforming the sediment) are typical early diagenetic products; sedimentary structures typical of subaerial exposure were never evidenced. However, inter- 
pretation of some features remains questionable, as the subvertical to vertical orientation in anhydrite which might represent either pseudomorphs of selenite gypsum, or early diagenetic nodules as described in the modern sabkhas of Persian Gulf (Shearman, 1966, 1971). At this site, one important question concerns anhydrite formation and gypsum preservation in relation with burial of these sediments and the high thermal gradient. Anhydrite occurs as a major constituent at about $315 \mathrm{~m}$ (Core $34 \mathrm{R}$ ) where in-situ temperature is about $55^{\circ} \mathrm{C}$ and pore water salinity ranges between $50 \%$ (Core $20 \mathrm{R}$ ) and $65 \%$ (Core 38R) (Kastens, Mascle, et al., 1987). Under these conditions, anhydrite would be the stable calcium sulfate phase and gypsum would be converted to anhydrite (Hardie, 1967; MacDonald, 1953; Blount and Dickson, 1973). Metastability of gypsum down to $720 \mathrm{~m}$ where in-situ temperatures are close to $110^{\circ} \mathrm{C}$ is therefore highly questionable. It is emphasized that gypsum is the product of rapid rehydration of anhydrite when the cores were submitted to atmospheric pressure and low external temperature once on shipboard, both factors acting to lower the anhydrite-gypsum temperature transition (MacDonald, 1953; Blount and Dickson, 1973).

\section{Stable Isotopes}

The seven samples of sulfate analyzed for stable isotopes come from the main gypsum/anhydrite-rich level, between $349.54 \mathrm{~m}$ and $415.89 \mathrm{~m}$ sub-bottom depth (Table 1).

The $\delta$ values $\left(+13.7<\delta^{18} \mathrm{O}<+17.5 ;+19.8<\delta^{34} \mathrm{~S}<\right.$ $+24.5)$ are basically included within the range of $\delta$ values obtained for sulfate deposited at Sites 653 and 654 (Fig. 2). These results emphasize the same marine origin at the three sites of the aqueous sulfate of solutions from which gypsum or anhydrite crystallized. This conclusion, however, does not preclude the possible reworking by marine or continental waters of previously deposited sulfate evaporites, either as detrital components, or as ionic components in solutions which became further saturated relative to gypsum or anhydrite through evaporation. Petrographic observations have shown that at Site 652, sulfate nodules are often reworked, but gypsum or anhydrite have also crystallized in situ either as cement of nodules or as microlaminae with fibrous structures. During crystallization of these primary facies, the sulfated solutions provided to the basin had to be introduced at the saturation level for gypsum/anhydrite minerals, because the primary carbonate phases of the evaporite-bearing layers do not show enrichment in ${ }^{18} \mathrm{O}$ evidencing in-situ water evaporation. It is therefore emphasized that brines of marine origin, probably coming from adjacent evaporitic lagoons, were infiltrated by lateral seepage towards the lacustrine basin located at Site 652 .

\section{Carbonates}

\section{Petrography and Mineralogy}

The carbonate fraction of the lowermost Pliocene sediments is exclusively represented by near stoichiometric calcite $\left(\mathrm{d}_{104}=\right.$ $3.034 \AA)$, stoichiometric dolomite $\left(d_{104}=2.886 \AA\right)$ is first noted in the Miocene-Pliocene transitional interval. The pre-Pliocene series is subdivided into two zones with respect to the carbonate mineralogy.

In the upper zone, down to $410 \mathrm{~m}$ sub-bottom depth, the dominant carbonate phase is calcite generally associated with two phases of dolomite; the values of $d_{104}$ of calcite are rather homogeneous and range between $3.030 \AA$ and $3.033 \AA$ indicating near-stoichiometric to low-Mg composition. One phase of dolomite appears to be nearly stoichiometric $\left(2.884<\mathrm{d}_{104} \AA\right.$ $<2.891$ ). The other phase of dolomite, for which $d_{104}$ values range between $2.893 \AA$ and $2.918 \AA$, might be calcian dolomite or ankerite. The simultaneous occurrence of the two phases of dolomite makes it difficult to precisely identify ankerite in x-ray diffraction diagrams. SEM observations show two different fabrics of carbonate particles: round grains $(\mathrm{Pl} .8,1)$ and euhedral rhomboedra (Pl. 8, 2-6); this latter carbonate facies for which ORTEC analyses identify $\mathrm{Fe}-\mathrm{Mg}-\mathrm{Ca}$ elements is considered to be authigenic ankerite. Euhedral Fe-rich dolomite is also commonly observed in the nodular to bedded anhydrite where it may constitute more than $50 \%$ of the volume of sediment $(\mathrm{Pl}$. $8,4-6)$. In thin sections, reworked carbonates clearly show rounded fragments with reworked foraminifers in some cases.

Below $470 \mathrm{~m}$ sub-bottom depth, the ratio of dolomite relative to calcite increases sharply and several levels are exclusively dolomite. Calcites $\left(3.030<\mathrm{d}_{104} \AA<3.034\right)$ have stoichiometric to low $\mathrm{Mg}$ compositions; the values of $\mathrm{d}_{104}$ of dolomites indicate varying composition from stoichiometry $(2.886 \AA)$ to Fe-rich $(2.900 \AA$ to $2.910 \AA)$. Other minerals associated in variable amounts with carbonates include quartz, clays, feldspars, gypsum, anhydrite, and halite. Halite is not primary although molds of cubic crystals are present at a few levels in the cores (Kastens, Mascle, et al., 1987); it was more probably crystallized by evaporation of interstitial brines during drying of sediments in laboratory. The intercalation at the level $652 \mathrm{~A}-64 \mathrm{R}-1,110-112 \mathrm{~cm}$, at $578.60 \mathrm{~m}$ sub-bottom depth, of a $2-\mathrm{cm}$ white layer, with a pseudonodular structure resembling anhydrite, was identified by $x-$ ray diffraction as kaolinite with small amounts of quartz; these nodules with brecciated internal structure possibly result from the reworking of a continental alteration crust.

\section{Stable Isotopes}

The entire sequence of $530 \mathrm{~m}$ of carbonate sediments, from $181.39 \mathrm{~m}$ down to $716.16 \mathrm{~m}$ sub-bottom depth, was investigated for oxygen and carbon isotopes in order to recognize the peculiar geochemical signals related to the depositional and diagenetic environments.

The samples selected for stable isotope analysis were mostly fine-grained sediments (mudstones and siltstones) in which the detrital minerals are silicates while carbonates are primary and authigenic phases as indicated by microscopic observations.

From a general point of view, each carbonate mineral phase (i.e., calcite, stoichiometric dolomite, nonstoichiometric dolomite) is characterized by specific $\delta^{18} \mathrm{O}$ and $\delta^{13} \mathrm{C}$ values (Table 4 , Figs. 4,5 ). This means that these carbonates were generated under different conditions of temperature and/or of $\delta^{18} \mathrm{O}$ water, i.e., during different stages of crystallization since the time of deposition, through early and late diagenesis.

\section{Calcites}

The oxygen and carbon isotope compositions $(+0.86<$ $\left.\delta^{18} \mathrm{O}<+1.17 ;+0.22<\delta^{13} \mathrm{C}<+0.60\right)$ of calcite of the lowermost Pliocene sediments are conspicuously indicative of deposition in open marine conditions. Less than $10 \mathrm{~m}$ below, after crossing the inferred Pliocene-Miocene boundary, the $\delta$ values of calcite lower abruptly and reach $-4.5 \pm 0.5$ for $\delta^{18} \mathrm{O}$ and $-1.0 \pm 0.5$ for $\delta^{13} \mathrm{C}$ (Fig. 4). Below about $400 \mathrm{~m}$ sub-bottom depth, the $\delta^{18} \mathrm{O}$ values drop to about $-5.7 \pm 0.7$ while $\delta^{13} \mathrm{C}$ values remain stable. The isotopic record of calcite thus provide significant information on the main environmental characteristics when calcite precipitated during Messinian times up to the onset of Pliocene.

The $>5 \%$ shift of $\delta^{18} \mathrm{O}$ values and the shift of nearly $2 \%$ of $\delta^{13} \mathrm{C}$ values of calcite which occur at the Miocene-Pliocene boundary can only be ascribed to major changes in the oxygen and carbon isotopic compositions of water at this time, because water temperatures could not have been significantly different (i.e., no more than a few degrees) for such a short period. Therefore, prior to Pliocene when marine waters invaded the basin, the sedimentation was mainly nonmarine and the basin was fed 
Table 4. Stable isotope compositions of carbonates at ODP Hole $652 \mathrm{~A}$. The $\delta^{18} \mathrm{O}$ values of dolomites are corrected by $-0.8 \%$ for the oxygen isotope fractionation effect that occurs during phosphoric acid extraction (Sharma and Clayton, 1965).

\begin{tabular}{|c|c|c|c|c|c|c|c|c|c|c|}
\hline $\begin{array}{l}\text { Core, section, } \\
\text { interval }(\mathrm{cm})\end{array}$ & $\begin{array}{l}\text { Depth } \\
\text { (mbsf) }\end{array}$ & $\begin{array}{c}\mathrm{d} \AA \AA \text { (104) } \\
\text { Calcite }\end{array}$ & $\begin{array}{l}\mathrm{d} \AA \text { (104) } \\
\text { Dolomite }\end{array}$ & $\begin{array}{l}\delta^{18} \mathrm{O} \\
\text { Calcite }\end{array}$ & $\begin{array}{l}\delta^{13} \mathrm{C} \\
\text { Calcite }\end{array}$ & $\begin{array}{c}\delta^{18} \mathrm{O} \\
\text { Dolomite }\end{array}$ & $\begin{array}{c}\delta^{13} \mathrm{C} \\
\text { Dolomite }\end{array}$ & $\begin{array}{l}\% \text { Dolomite/ } \\
\text { total carbonate }\end{array}$ & $\begin{array}{c}\Delta^{18} \mathrm{O} \\
\begin{array}{c}\text { Dolomite- } \\
\text { calcite }\end{array}\end{array}$ & $\begin{array}{c}\Delta^{13} \mathrm{C} \\
\text { Dolomite } \\
\text { calcite }\end{array}$ \\
\hline \multicolumn{11}{|l|}{$107-652 \mathrm{~A}-$} \\
\hline $20 \mathrm{R}-1,119-121$ & 181.39 & 3.034 & - & +1.17 & +0.22 & & & 0 & & \\
\hline $20 \mathrm{R}-2,100-102$ & 182.70 & 3.034 & - & +0.86 & +0.34 & & & 0 & & \\
\hline $20 \mathrm{R}-3,110-112$ & 184.30 & 3.034 & - & +1.08 & +0.42 & & & 0 & & \\
\hline $20 \mathrm{R}-4,119-121$ & 185.90 & 3.033 & - & +1.02 & +0.60 & & & 0 & & \\
\hline $20 \mathrm{R}-5,119-121$ & 187.40 & 3.035 & 2.886 & +0.56 & +0.57 & +1.76 & -2.90 & 5 & 1.20 & -3.47 \\
\hline 20R-6, 110-112 & 188.80 & 3.032 & 2.896 & -2.06 & -1.65 & +0.95 & -2.11 & 17 & 3.01 & -0.46 \\
\hline 21R-2, 90-94 & 192.50 & 3.031 & 2.886 & -4.27 & -0.90 & -2.53 & +1.00 & 10 & 1.74 & 1.90 \\
\hline $22 \mathrm{R}-2,35-39$ & 201.55 & 3.030 & 2.887 & -3.77 & -0.65 & & & 3 & & \\
\hline $23 \mathrm{R}-1,34-38$ & 209.44 & 3.032 & 2.891 & -4.19 & -0.90 & -1.18 & +0.12 & 5 & 3.01 & 1.02 \\
\hline $23 \mathrm{R}-2,82-86$ & 211.40 & 3.031 & $2.885 ; 2.893$ & -4.52 & -1.09 & & & 4 & & \\
\hline $24 \mathrm{R}-1,74-75$ & 219.44 & 3.033 & $2.888 ; 2.910$ & -4.19 & -0.85 & -1.82 & +0.78 & 12 & 2.37 & 1.63 \\
\hline $24 \mathrm{R}-2,132-134$ & 221.52 & 3.032 & & -2.90 & -0.87 & & & 4 & & \\
\hline $25 \mathrm{R}-2,20-23$ & 230.10 & 3.032 & 2.898 & -4.19 & -1.03 & & & 4 & & \\
\hline $26 \mathrm{R}-2,85-87$ & 240.45 & 3.031 & $2.888 ; 2.912$ & -4.75 & -0.66 & -1.36 & +1.03 & 3 & 3.39 & 1.69 \\
\hline $27 R-2,36-40$ & 249.56 & 3.030 & $2.886 ; 2.908$ & -4.47 & -1.08 & -1.26 & +1.48 & 13 & 3.21 & 2.56 \\
\hline $28 \mathrm{R}-2,35-39$ & 259.25 & 3.032 & $2.888 ; 2.912$ & -4.12 & -0.75 & -1.14 & +1.23 & 12 & 2.98 & 1.98 \\
\hline 29R-2, 33-37 & 268.93 & 3.031 & $2.889 ; 2.913$ & -4.73 & -1.26 & -1.02 & +1.22 & 11 & 3.71 & 2.48 \\
\hline $30 \mathrm{R}-2,46-50$ & 278.66 & 3.030 & $2.887 ; 2.909$ & -4.57 & -0.61 & -1.65 & +0.51 & 14 & 2.92 & 1.12 \\
\hline $31 \mathrm{R}-2,96-100$ & 288.76 & 3.030 & $2.888 ; 2.911$ & -4.73 & -1.28 & -1.92 & +0.03 & 24 & 2.81 & 1.31 \\
\hline $32 \mathrm{R}-2,81-83$ & 298.21 & 3.030 & $2.888 ; 2.912$ & -4.64 & -0.91 & -0.85 & +0.54 & 11 & 3.79 & 1.45 \\
\hline $33 R-2,47-49$ & 307.57 & 3.030 & $2.889 ; 2.916$ & -4.67 & -0.73 & -1.50 & +0.84 & 4 & 3.17 & 1.57 \\
\hline $34 \mathrm{R}-1,133-135$ & 316.63 & 3.031 & $2.888 ; 2.914$ & -4.49 & -0.99 & -2.07 & +0.51 & 14 & 2.42 & 1.50 \\
\hline $34 \mathrm{R}-2,92-94$ & 317.72 & 3.031 & $2.882 ; 2.910$ & -3.92 & -1.19 & -2.47 & +0.16 & 8 & 1.45 & 1.35 \\
\hline 34R-CC (2-4) & 325.80 & 3.030 & $2.886 ; 2.902$ & -5.03 & -1.81 & -1.47 & +0.50 & 10 & 3.56 & 2.31 \\
\hline $35 \mathrm{R}-1,36-38$ & 325.36 & 3.031 & $2.891 ; 2.914$ & -4.34 & -2.45 & -0.58 & -0.33 & 5 & 3.76 & 2.12 \\
\hline $35 \mathrm{R}-\mathrm{CC}(9-11)$ & 335.59 & 3.031 & $2.888 ; 2.918$ & -3.68 & -1.69 & -1.92 & +1.85 & 12 & 1.76 & 3.54 \\
\hline $37 \mathrm{R}-1,96-99$ & 345.26 & 3.032 & $2.884 ; 2.905$ & -3.37 & -1.80 & -0.92 & -1.54 & $?$ & 2.45 & 0.26 \\
\hline $37 \mathrm{R}-2,90-93$ & 346.70 & 3.033 & $2.887 ; 2.908$ & -3.82 & -1.16 & +1.49 & -1.75 & 27 & 5.31 & -0.59 \\
\hline $37 \mathrm{R}-3,36-39$ & 347.66 & 3.031 & $2.889 ; 2.909$ & & & +0.65 & -0.92 & 56 & & \\
\hline $37 R-4,36-38$ & 349.16 & 3.033 & $2.892 ; 2.906$ & -3.91 & -1.19 & & & 23 & & \\
\hline $37 R-4,90-92$ & 349.70 & 3.033 & $2.888 ; 2.910$ & -4.71 & -1.09 & -2.24 & -0.62 & 13 & 2.47 & 0.47 \\
\hline $37 \mathrm{R}-5,92-95$ & 351.22 & 3.033 & & -3.61 & -1.29 & & & 0 & & \\
\hline $38 \mathrm{R}-2,36-40$ & 355.86 & 3.031 & & -4.38 & -1.11 & & & 0 & & \\
\hline $38 \mathrm{R}-2,95-97$ & 356.45 & 3.031 & $2.889 ; 2.909$ & -4.08 & -1.30 & & & 18 & & \\
\hline $38 \mathrm{R}-5,92-94$ & 360.92 & 3.031 & $2.888 ; 2.909$ & -4.05 & -0.92 & -1.11 & +0.36 & 17 & 2.94 & 1.28 \\
\hline $39 \mathrm{R}-1,32-35$ & 364.02 & 3.033 & $2.886 ; 2.908$ & -3.83 & -0.79 & -1.40 & +0.80 & 9 & 2.43 & 1.59 \\
\hline $39 R-3,90-93$ & 367.60 & 3.032 & $2.886 ; 2.904$ & -3.92 & -0.88 & -1.27 & -0.11 & 15 & 2.65 & 0.77 \\
\hline $39 R-4,32-35$ & 368.52 & 3.031 & $2.890 ; 2.912$ & -4.18 & -0.88 & -1.44 & +0.64 & 14 & 2.74 & 1.52 \\
\hline $39 \mathrm{R}-5,103-105$ & 370.73 & 3.030 & $2.890 ; 2.906$ & -3.78 & -0.87 & -1.96 & +0.71 & 18 & 1.82 & 1.58 \\
\hline $41 \mathrm{R}-5,100-102$ & 390.00 & 3.031 & $2.885 ; 2.910$ & -4.10 & -1.29 & -1.49 & +0.92 & 11 & 2.61 & 2.21 \\
\hline $43 R-5,109-111$ & 409.49 & 3.032 & $2.885 ; 2.891$ & -6.29 & -1.96 & -2.00 & +0.60 & 16 & 4.29 & 2.56 \\
\hline 50R-2, 36-39 & 471.86 & & 2.890 & & & -5.10 & -0.82 & 100 & & \\
\hline $51 R-4,33-37$ & 484.43 & 3.030 & 2.890 & -5.64 & -1.27 & +0.66 & +1.69 & 9 & 6.30 & 2.96 \\
\hline $52 \mathrm{R}-3,19-20$ & 492.39 & & 2.899 & & & -6.68 & -0.81 & 100 & & \\
\hline $53 R-3,76-79$ & 502.56 & 3.033 & 2.889 & -5.53 & -0.99 & -3.16 & +0.39 & 21 & 2.37 & 1.38 \\
\hline $54 \mathrm{R}-1,37-39$ & 508.87 & & 2.896 & & & -5.07 & -0.90 & 100 & & \\
\hline $55 \mathrm{R}-3,92-95$ & 522.02 & & 2.895 & & & -5.02 & -1.06 & 100 & & \\
\hline $56 R-4,35-37$ & 532.65 & & 2.898 & & & -5.52 & -0.97 & 100 & & \\
\hline $57 \mathrm{R}-3,30-32$ & 540.70 & & 2.902 & & & -5.86 & -1.31 & 100 & & \\
\hline $58 \mathrm{R}-4,8-10$ & 551.18 & & 2.895 & & & -6.17 & -1.57 & 100 & & \\
\hline $58 \mathrm{R}-4,36-40$ & 551.46 & & 2.894 & & & -6.27 & -2.66 & 100 & & \\
\hline $58 R-5,36-40$ & 552.96 & & 2.892 & & & -6.81 & -2.64 & 100 & & \\
\hline $58 R-5,74-76$ & 553.34 & & $?$ & & & -6.07 & -2.64 & 100 & & \\
\hline $59 \mathrm{R}-4,30-32$ & 561.10 & 3.031 & ? & -4.67 & -0.87 & -1.95 & +0.63 & 30 & 2.72 & 1.50 \\
\hline 60R-3, 93-95 & 569.93 & & 2.900 & & & -6.54 & -2.16 & 100 & & \\
\hline $61 R-4,36-38$ & 580.46 & & 2.899 & & & -5.71 & -1.42 & 100 & & \\
\hline $62 R-3,35-37$ & 588.55 & & 2.900 & & & -6.47 & -1.15 & 100 & & \\
\hline $63 \mathrm{R}-1,26-28$ & 595.16 & & 2.906 & & & -6.94 & -0.91 & 100 & & \\
\hline $64 R-2,41-43$ & 606.41 & & 2.890 & & & -6.04 & -1.23 & 100 & & \\
\hline $65 \mathrm{R}-1,30-33$ & 614.50 & & 2.893 & & & -5.66 & -1.20 & 100 & & \\
\hline $66 R-4,36-39$ & 629.36 & 3.032 & 2.890 & -5.31 & -1.20 & -2.12 & -0.79 & 16 & 3.19 & 0.41 \\
\hline $67 R-1,91-95$ & 635.11 & 3.032 & 2.896 & -5.29 & -0.82 & & & 14 & & \\
\hline $68 \mathrm{R}-5,1-9$ & 649.81 & 3.032 & 2.888 & -4.72 & -0.77 & -1.80 & +0.58 & 24 & 2.92 & 1.35 \\
\hline $69 \mathrm{R}-1,120-121$ & 654.60 & & 2.896 & & & -3.59 & -2.37 & 100 & & \\
\hline $70 \mathrm{R}-3,7-13$ & 666.17 & & 2.896 & & & -4.64 & -1.21 & 100 & & \\
\hline 70R-4, 79-81 & 668.39 & & 2.902 & & & -6.22 & -2.00 & 100 & & \\
\hline $70 R-4,126-128$ & 668.86 & & 2.892 & & & -2.97 & -1.79 & 100 & & \\
\hline 7IR-1, 15-18 & 672.95 & 3.032 & 2.889 & -5.09 & -0.94 & -2.04 & -0.19 & 40 & 3.05 & 0.75 \\
\hline $71 \mathrm{R}-1,146-148$ & 674.26 & 3.031 & $2.887 ; 2.899$ & -5.11 & -0.97 & -2.17 & -0.91 & 49 & & \\
\hline $72 \mathrm{R}-1,36-38$ & 682.86 & 3.031 & 2.886 & -5.12 & -0.85 & & & 10 & & \\
\hline $73 R-1,91-95$ & 693.11 & 3.031 & 2.902 & -6.51 & -2.43 & -5.48 & -0.58 & 23 & 1.03 & 1.85 \\
\hline $74 \mathrm{R}-4,88-90$ & 707.28 & 3.030 & $2.893 ; 2.909$ & -5.36 & -0.96 & & & 13 & & \\
\hline $75 \mathrm{R}-3,115-117$ & 714.15 & & 2.898 & & & -2.17 & -1.39 & 100 & & \\
\hline $75 R-5,16-22$ & 716.16 & 3.030 & $2.887 ; 2.902$ & -5.47 & -1.32 & -1.10 & -0.45 & 66 & 4.37 & 0.87 \\
\hline
\end{tabular}




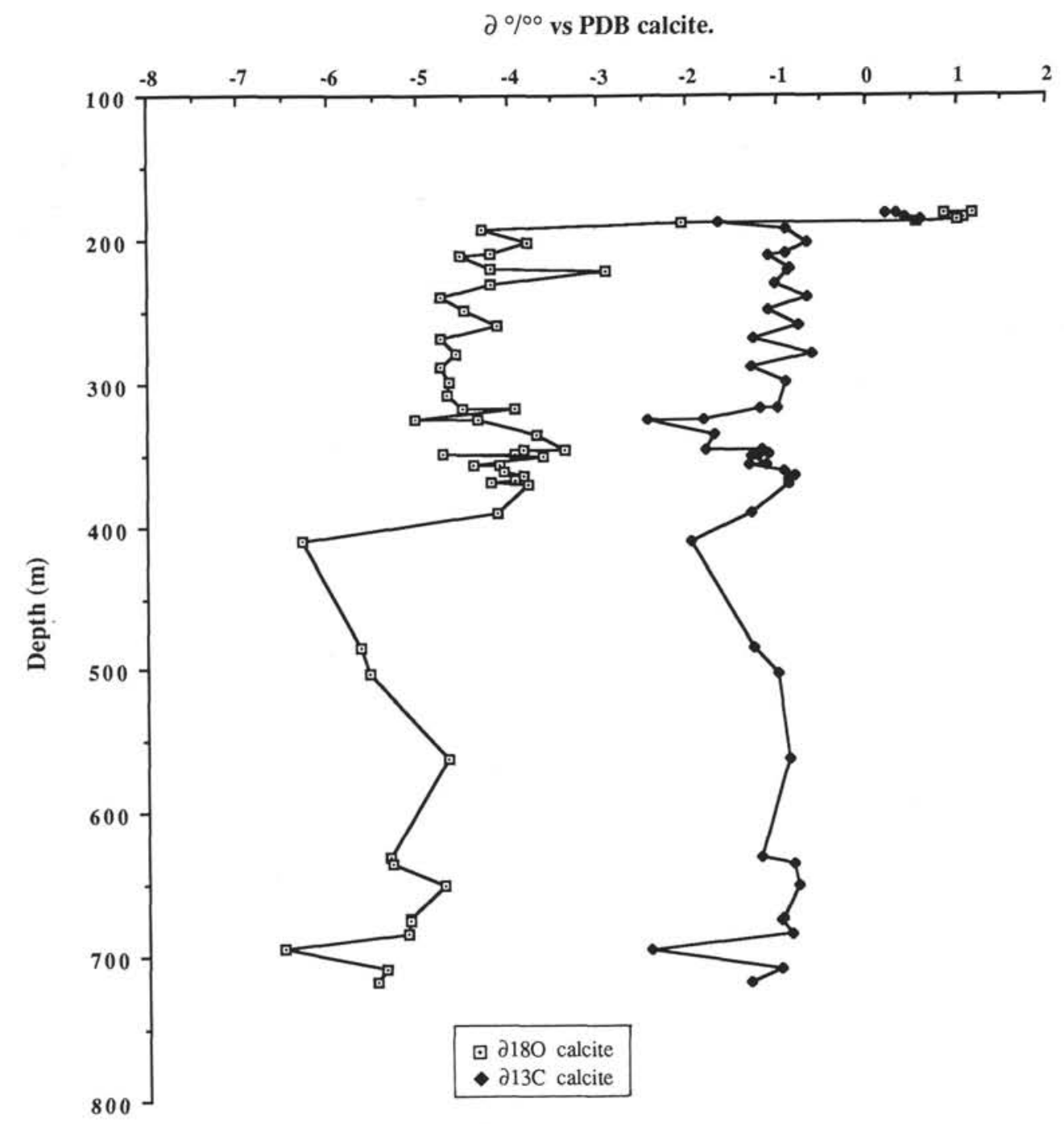

Figure 4. Variations with depth of $\delta^{18} \mathrm{O}$ and $\delta^{13} \mathrm{C}$ values of calcite at ODP Hole 652A.

by continental waters. The $\delta^{13} \mathrm{C}$ values of the $\mathrm{\Sigma CO}_{2}$ reservoir of waters were rather constant throughout late Miocene times but they were lower than during early Pliocene; this carbon isotope signal is related to the negative carbon shift in the Messinian which is registered in all oceans and corresponds to a global change in the mass-balance of the different carbon reservoirs, especially the $\mathrm{\Sigma CO}_{2}$ of ocean waters and the atmospheric $\mathrm{CO}_{2}$ (Keigwin and Shackleton, 1980; Vincent and Berger, 1980; Savin et al., 1981; Shackleton et al., 1984).

The maximum $2.0 \%$ decrease of $\delta^{18} \mathrm{O}$ values, which is recorded in calcite below $400 \mathrm{~m}$ down to $720 \mathrm{~m}$, is attributed to the effect of recrystallization during burial diagenesis. Importantly, the corresponding temperature increase of about $9^{\circ} \mathrm{C}$ indicates that the geothermal gradient was only about $3^{\circ} \mathrm{C} / 100 \mathrm{~m}$ before early Pliocene. This implies that the present-day high geothermal gradient was developed after deposition of at least this portion of the late Miocene sequence, when the subsidence of the basin was initiated.

\section{Dolomites}

Mineralogical determination by x-ray diffraction has revealed that two different dolomites, stoichiometric and nonstoichiometric (iron-rich), are present in the sediment, either commonly in assemblages and associated with calcite all along the sedimentary sequence, or as a single phase for the nonstoichiome- tric dolomite in sediments below $450 \mathrm{~m}$ sub-bottom depth (Table 4, Fig. 5). As mentioned previously for dolomite mixtures, isotope data concern the unique stoichiometric dolomite which is the major component (often more than 90\%) in these mixtures. Two sets of $\delta$ values on stoichiometric and nonstoichiometric dolomites are thus available. When plotting the $\delta^{18} \mathrm{O}$ and $\delta^{13} \mathrm{C}$ values, as well as the $\delta^{18} \mathrm{O}$ and $\mathrm{d}_{104}$ values of these dolomites (Figs. 6, 7), two separate groupings are revealed. The group of stoichiometric dolomites is characterized by the highest $\delta^{18} \mathrm{O}$ values $(-3.16$ to +1.76$)$ and variable $\delta^{13} \mathrm{C}$ values $(-2.90$ to $+1.85)$, while the group of nonstoichiometric dolomites exhibits the lowest $\delta^{18} \mathrm{O}$ values $(-6.94$ to -2.17$)$ and negative $\delta^{13} \mathrm{C}$ values $(-2.64$ to -0.58$)$. These isotopic and mineralogical differences of the two dolomite groupings indicates that they were crystallized during two different diagenetic stages where geochemical conditions changed substantially.

The $\Delta^{18} \mathrm{O}$ values, i.e., the differences between the $\delta^{18} \mathrm{O}$ values of stoichiometric dolomites and coexisting calcites, range between 0 and $+6.2 \%$ around an average of $+3.0 \%$ (Table 4 ). These values fit very well with the theoretical values of the oxygen isotope enrichment factor $\left(\epsilon^{18} \mathrm{O}\right)$ between dolomite and calcite precipitated at sedimentary temperatures (Northrop and Clayton, 1966; Fritz and Smith, 1970; Matthews and Katz, 1977). The same range is also observed for the $\Delta^{13} \mathrm{C}$ difference $(0$ to $+3.5 \%$ ) (Table 4) measured between dolomite and calcite and 
$\partial 180 \%{ }^{\circ}$ vs PDB dolomite

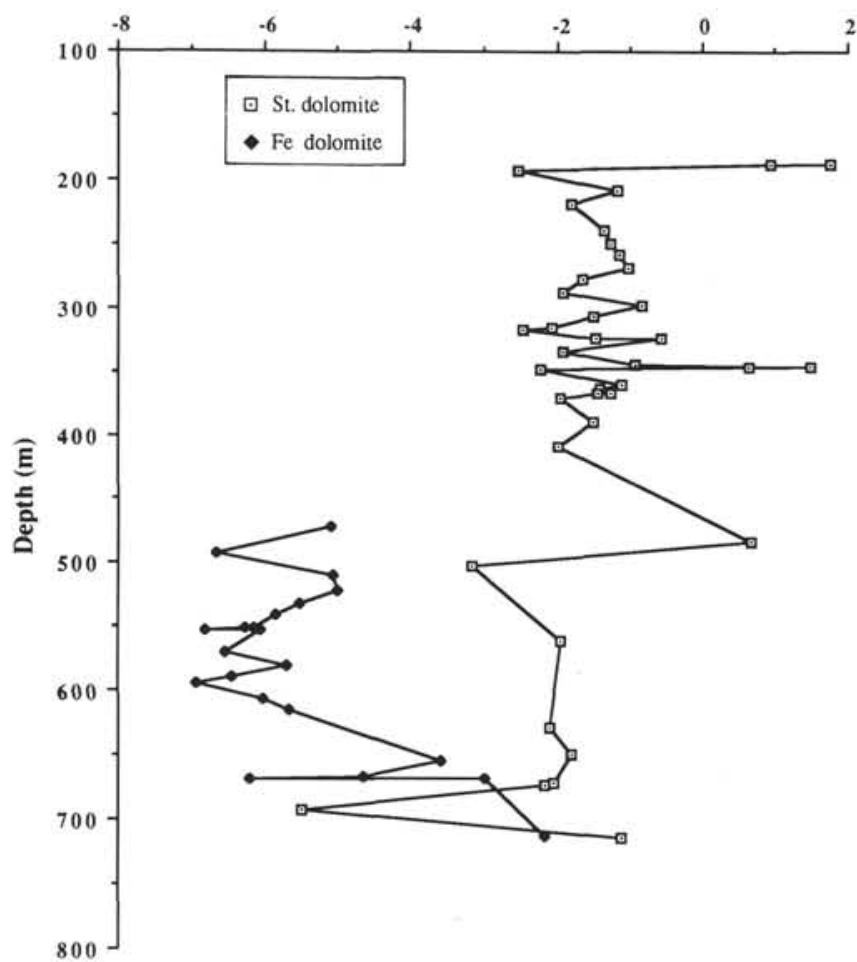

B

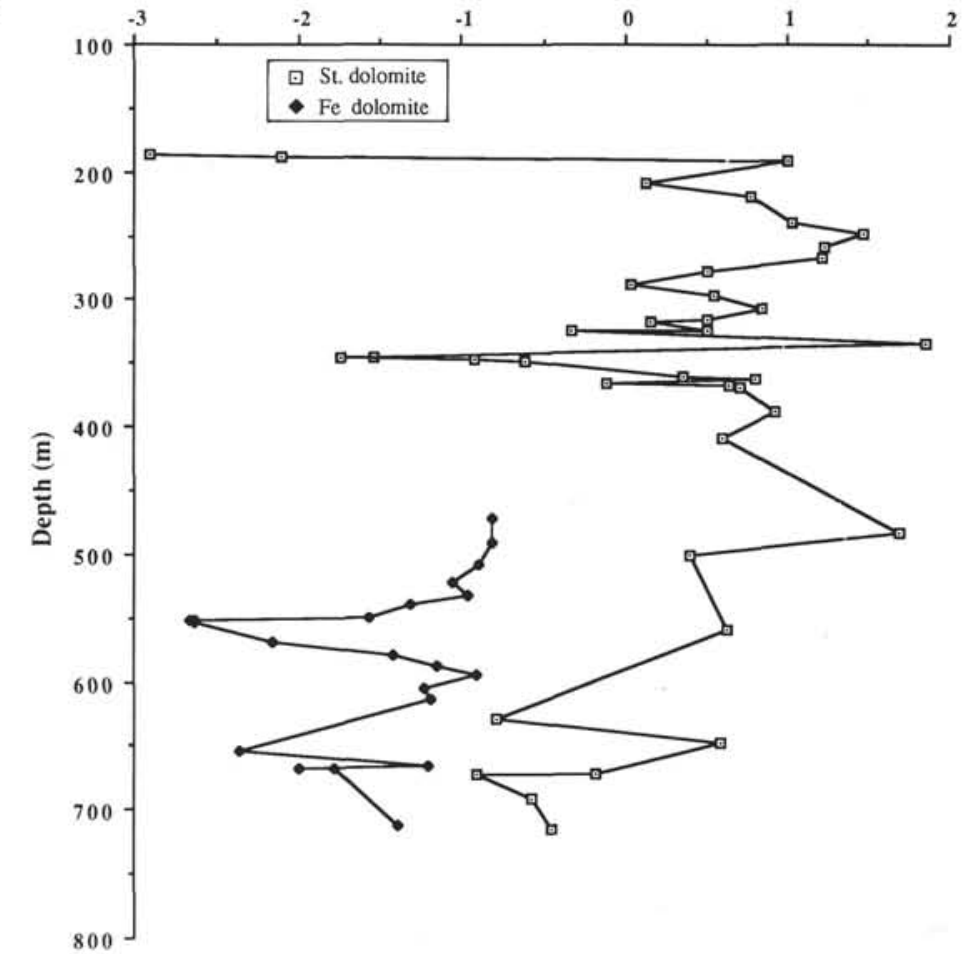

Figure 5. Variations with depth of $\delta^{18} \mathrm{O}(\mathrm{A})$ and $\delta^{13} \mathrm{C}(\mathrm{B})$ values of the stoichiometric dolomites (st. dol.) and iron-rich (Fe dol.) dolomites at ODP Hole $652 \mathrm{~A}$.

the theoretical $\epsilon^{13} \mathrm{C}$ value between dolomite and calcite of lowtemperature assemblages (Sheppard and Schwarcz, 1970). These results emphasize that, in all the studied samples, calcite and stoichiometric dolomite constitute a real mineralogical pair, i.e., they were precipitated contemporaneously at the same low temperature and from the same solutions. In other words, stoichiometric dolomites belong to a very early diagenetic stage as does the coexisting calcite.

The $\delta^{18} \mathrm{O}$ values of the nonstoichiometric dolomites (Fe-rich dolomites) show a rather regular trend to decrease upward by $4.8 \%$ at maximum, along the lowermost $250 \mathrm{~m}$ of the sequence (i.e., between 470 and $720 \mathrm{~m}$ sub-bottom depth). This $\delta^{18} \mathrm{O}$ variation would correspond to increasing temperatures by $23^{\circ} \mathrm{C}$ if there was no change of the $\delta^{18} \mathrm{O}$ value of water during dolomite formation; in such a case, the calculated geothermal gradient would be close to $9^{\circ} \mathrm{C} / 100 \mathrm{~m}$. Conversely, if the high presentday geothermal gradient was in effect during the crystallization of Fe-rich dolomites, the $\delta^{18} \mathrm{O}$ value of pore waters might be higher than before by about $3 \%$ at maximum for a geothermal gradient of $14^{\circ} \mathrm{C} / 100 \mathrm{~m}$. Although very speculative, this assumption does not seem unrealistic because recrystallization of carbonates at somewhat high temperatures causes increases in the $\delta^{18} \mathrm{O}$ of pore waters (Land, 1980; Lawrence, 1988). Anyway, the dolomitizing solutions were obviously modified pore waters since iron was incorporated within the crystal lattice of dolomites. Reducing conditions were probably prevalent in these solutions to account for the presence $\mathrm{Fe}^{2+}$ ions, and would also explain the fairly low $\delta^{13} \mathrm{C}$ values of dolomites. These dolomites which were generated during a late diagenetic stage, date the beginning of subsidence of the basin. Furthermore, the evolution with depth of $\delta^{18} \mathrm{O}$ values of the Fe-rich dolomites indicates that the flow of hot dolomitizing fluids was ascending through the sedimentary column. At the initiation of the subsidence process, the migrating fluids had moderate temperatures and reached only the lowest levels; as the subsidence progressed, pore solutions became hotter and progressively dolomitized the upper levels. The amount of Fe-rich dolomites in the pre-Pliocene sedimentary sequence drops sharply above $400 \mathrm{~m}$; their disappearance above $220 \mathrm{~m}$ sub-bottom depth indicates that the influence of this late diagenetic event ended just before Pliocene time.

\section{SUMMARY}

The main conclusions deduced from sedimentology and stable isotope geochemistry, concerning the paleoenvironments of sedimentation and diagenesis of Messinian evaporites from the central Tyrrhenian basin, are consistently in agreement with the previous statements based on the study of other occurrences of Messinian evaporites from Mediterranean (Fontes et al., 1973a, b; Pierre, 1974, 1982; Pierre and Fontes, 1978, 1979; Rouchy, 1982; Rouchy and Pierre, 1979).

At the three Sites 652,653 , and 654 , oxygen and sulfur isotope compositions of gypsum/anhydrite deposits argue for the unique marine origin of the aqueous sulfate of solutions from which these minerals precipitated. In these restricted basins, activity of sulfate reducing bacteria, evidenced by the variations of $\delta$ values of sulfate, was conditioned by the amounts of organic material (principally of algal origin) available. Most petrographic facies are indicators of shallow water deposition (laminated and selenitic gypsum) or of interstitial crystallization (lenticular gypsum and nodular anhydrite). Diagenetic fabrics include mainly early and late anhydritization of gypsum related to increasing ambient temperatures (due either to climate or to increasing burial); gypsification of anhydrite observed at Site 652 is more probably an artifact due to the rapid and sharp drops of pressure and temperature when the cores were raised aboard.

These overall results mean that during Messinian, at least at the times of sulfate-evaporites deposition, the Tyrrhenian basin 


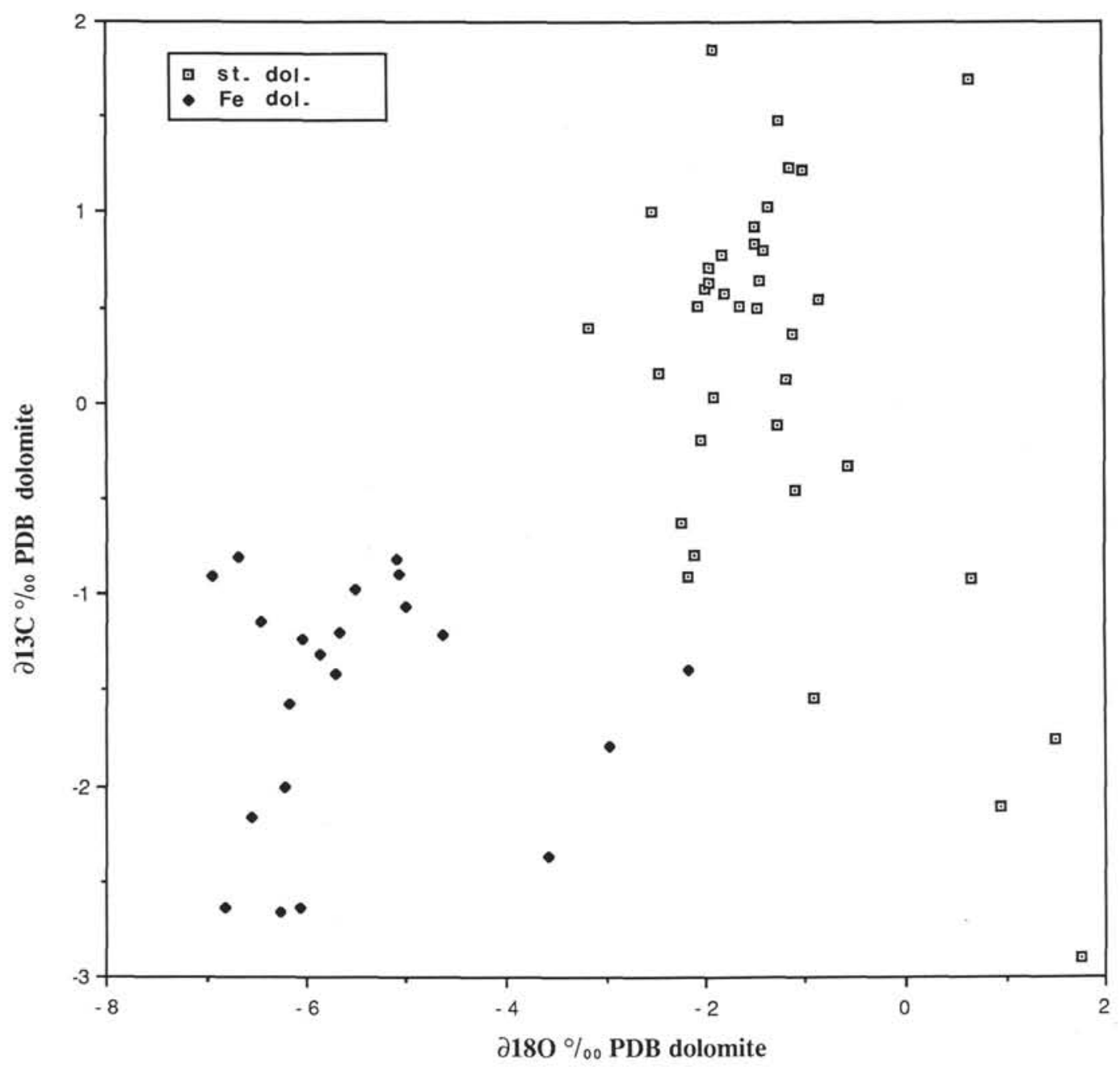

Figure 6. Relationship between $\delta^{18} 0$ and $\delta^{13} \mathrm{C}$ values in the stoichiometric dolomites (st. dol.) and iron-rich dolomites (Fe dol.) at ODP Hole 652A.

had shallow waters and was connected with the Atlantic which provided seawater through the western Mediterranean basins.

Oxygen and carbon isotope compositions of carbonates intercalated or associated with sulfate evaporites emphasize large and rapid fluctuations in the evaporation/dilution mass balance of the waters where carbonate crystallization occurred. In the area corresponding to Site 652 , waters supplied to the basin were almost of meteoric origin, and carbonate sediments were deposited subaqueously. Sulfate minerals crystallized from marine-derived brines which were episodically introduced in this lacustrine basin, probably by lateral seepage from adjacent basinal areas. Furthermore, at this site, the very low $\delta^{18} \mathrm{O}$ values of authigenic Fe-rich dolomites record a late diagenetic event related to the introduction of hot mineralizing fluids; this event began during Messinian when the subsidence initiated in this part of the Tyrrhenian basin, and ended just before Pliocene. In that respect, the Messinian sequence at Site 652 is obviously prerift to syn-rift, as stated previously by several authors (Moussat, 1983; Rehault et al., 1987; Malinverno and Ryan, 1986) and by the Shipboard Scientific Party of ODP Leg 107 (Kastens, Mascle, et al., 1987; Kastens, Mascle, et al., 1988).

\section{ACKNOWLEDGMENTS}

Contribution 39 of the C.N.R.S.-I.N.S.U.-D.B.T. ("Message sédimentaire"). This study was partly supported by the A.S.P.-O.D.P. program of the Centre National de la Recherche Scientifique and by the D.B.T. program of the Institut National des Sciences de l'Univers.
The authors thank Dr. C. Müller, D. Noel, and M. Servant-Vildary for their help for determination of diatoms and nannoplankton; they are grateful to Prof. I. R. Kaplan, Dr. K. Kastens, Dr. J. Mascle, Dr. F. McCoy, and Prof. B. C. Schreiber for useful comments and suggestions to improve the manuscript.

\section{REFERENCES}

Arakel, A. V., 1980. Genesis and diagenesis of Holocene evaporitic sediments in Hutt and Leeman lagoons, Western Australia. J. Sediment. Petrol., 50:1305-1326.

Blount, C. N., and Dickson, F. N., 1973. Gypsum-anhydrite equilibria in systems $\mathrm{CaSO}_{4}-\mathrm{H}_{2} \mathrm{O}$ and $\mathrm{CaSO}_{4}-\mathrm{NaCl}-\mathrm{H}_{2} \mathrm{O}$. Am. Mineral., 58: 323-331.

Butler, G. P., 1970. Secondary anhydrite from a sabkha, Northwest Gulf of California, Mexico. In Rau, J. L., and Dellwig, L. F. (Eds.), Third Symposium on Salt, Cleveland, Northern Ohio Geol. Soc., 153-155.

Ciaranfi, N., Dazzaro, L., Pieri, P., Rapisardi, L., and Sardella, A., 1978. Preliminary description of some Messinian evaporitic facies along the Abbruzi-Molise boundary. Mem. Soc. Geol. It., 16:251260.

Claypool, G. E., Holser, W. T., Kaplan, I. R., Sakai, H., and Zak, I., 1980. The age curves of sulfur and oxygen isotopes in marine sulfate and their mutual interpretation. Chem. Geol., 28:199-260.

Clayton, R. N., Jones, B. F., and Berner, R. A., 1968. Isotope studies of dolomite formation under sedimentary conditions. Geochim. Cosmochim. Acta, 32:415-432.

Filly, A., Pusset, M., and Letolle, R., 1975. L'analyse isotopique du soufre: problémes techniques. Analysis, 3:197-200. 
Fontes, J. C., Létolle, R., Nesteroff, W. D. and Ryan, W.B.F., 1973a. Oxygen, carbon, sulfur and hydrogen stable isotopes in carbonate and sulfate mineral phases of Neogene evaporites, sediments and in interstitial waters. In Ryan, W.B.F., Hsü, K. J., et al., Init. Repts., DSDP, 13, Washington (U.S. Govt. Printing Office), 788-796.

Fontes, J. C., Lepvrier, C., Méliéres, F., and Pierre, C., 1973b. Isotopes stables dans les carbonates évaporitiques du Miocéne supérieur de Méditerranée occidentale In Drooger, C. W. (Ed.), Messinian Events in the Mediterranean, Amsterdam (Koninklijke Nederlandse Akademie van Wetenschappen), 91-100.

Friedman, G. M., Sneh, A., and Owen, R. W., 1985. The Ras Muhammad Pool: Implications for the Gavish Sabkha In Friedman, G. M., and Krumbein, W. E. (Eds.), Hypersaline ecosystems. The Gavish Sabkha. Ecological Studies 53, Berlin (Springer-Verlag), 218-237.

Fritz, P., and Smith, D.G.W., 1970. The isotopic composition of secondary dolomites. Geochim. Cosmochim. Acta, 34:1161-1173.

Garrison, R. E., Schreiber, B. C., Bernouilli, D., Fabricius F. H., Kidd, R. E., and Méliéres, F., 1978. Sedimentary petrology and structures of Messinian evaporitic sediments in the Mediterranean Sea, leg 42A, Deep Sea Drilling Project. In Hsü, K. J., Montadert, L., et al., Init. Repts, DSDP, 42 (Pt. 1): Washington (U.S. Govt. Printing Office), 571-612.

Geisler-Cussey, D., 1986. Approche sédimentologique et géochimique des mécanismes générateurs de formations évaporitiques actuelles et fossiles. Marais salants de Camargue et du Levant espagnol, Messinien méditerranéen et Trias lorrain. Sci. Terre, 48:1-268.

Gunatilaka, A., 1975. Some aspects of the biology and sedimentology of laminated algal mats from Mannar Lagoon, Northwest Ceylon. Sediment. Geol., 14:275-300.

Hardie, A. H., and Eugster, H. P., 1971. The depositional environments of marine evaporites: a case for shallow, clastic accumulation. Sedimentology, 16:187-220.

Hardie, L. A., 1967. The gypsum-anhydrite equilibrium at one atmosphere pressure. Am. Mineral., 52:171-200.

Kastens, K., Mascle, J., Auroux, C., Bonatti, E., Broglia, C., Channell, J., Curzi, P., Emeis, K. C., Glaçon, G., Hasegawa, S., Hieke, W., Mascle, G., McCoy, F., McKenzie, J., Mendelson, J., Müller, C., Rehault, J. P., Robertson, A., Sartori, R., Sprovieri, R., Torii, M., 1986. La campagne 107 du Joides Resolution (Ocean Drilling Program) en Mer Tyrrhénienne: premiers résultats. C. R. Acad. Sci. Paris, 303:391-396.

Kastens, K., Mascle, J., et al., 1987. Proc. ODP, Init. Repts., 107: College Station, TX (Ocean Drilling Program).

Kastens, K., Mascle, J., Auroux, C., Bonatti, E., Broglia, C., Channel, J., Curzi, P., Emeis, K. C., Glaçon, G., Hasegawa, S., Hieke, W., Mascle, G., McCoy, F., McKenzie, J., Mendelson, J., Müller, C., Rehault, J. P., Robertson, A., Sartori, R., Sprovieri, R., Torii, M., 1988. ODP Leg 107 in the Tyrrhenian Sea: Insights into passive margin and back-arc basin evolution. Geol. Soc. Am. Bull.,100:11401156.

Keigwin, L. D., Jr., and Shackleton, N., 1980. Uppermost Miocene carbon isotope stratigraphy of a piston core in the equatorial Pacific. Nature, 284:613-614.

Land, L. S., 1980. The isotopic and trace element geochemistry of dolomite: the state of the art. SEPM Spec. Publ., 28:87-110.

Lawrence, J. R., 1989. The stable isotope geochemistry of deep sea pore water. In Fritz, P., and Fontes, J. C. (Eds.) Handbook of Environmental Isotope Geochemistry, Part 3: The marine environment, Elsevier, 317-356.

Lo Cicero, G., and Catalano, R., 1978. Facies and petrography of some Messinian evaporites of the Ciminna basin (Sicily). In Catalano, R., et al. (Eds.), Messinian evaporites in the Mediterranean. Mem. Soc. Geol. It., 16:63-81.

Longinelli, A., and Craig, H., 1967. Oxygen 18 variations in sulfate ions in sea water and saline lakes. Science, 156:56-59.

MacDonald, G.J.F., 1953. Anhydrite-gypsum equilibrium relations. Am. J. Sci., 235:247-272.

Malinverno, A., and Ryan, W.B.F., 1986. Extension in the Tyrrhenian sea and shortening in the Apennines as result of arc migration driven by sinking of the lithosphere. Tectonics, 5:227-245.

Matthews, A., and Katz, A., 1977. Oxygen isotope fractionation during the dolomitization of calcium carbonate. Geochim. Cosmochim. Acta, 41:1431-1438.

McCrea, J. M., 1950. On the isotopic chemistry of carbonates and a paleotemperature scale. J. Chem. Phys., 18:849-857
McKenzie, J. A., Jenkins, H. C., and Bennett, G. G., 1979. Stable isotope study of the cyclic diatomite-claystones from the Tripoli Formation, Sicily: a prelude to the Messinian Salinity Crisis. In Cita, M. B., and Wright, R. (Eds.), Geodynamic and biodynamic effects of the messinian Salinity Crisis in the Mediterranean. Palaeogeogr. Palaeoclimatol. Palaeoecol., 29:125-142.

Moiola, R. J., and Glover, E. D., 1965: Recent anhydrite from Clayton Playa, Nevada. Am. Mineral., 50:2063-2069.

Moussat, E., 1983. Evolution de la Mer Tyrrhénienne centrale et orientale et de ses marges septentrionales en relation avec la néotectonique dans l'arc calabrais. [Thesis]. Univ. Pierre et Marie Curie, Paris.

Nesteroff, W. D., 1973. Pétrographie des évaporites messiniennes de la Méditerranée. Comparaison des forages JOIDES-DSDP et des dépots du bassin de Sicile. In Drooger, C. W. (Ed.) Messinian Events in the Mediterranean, Proc. K. Ned. Akad. Wet. Ser. B. Geod. Sci., 111-123.

Northrop, D. A., and Clayton, R. N., 1966. Oxygen isotope fractionations in systems containing dolomite. J. Geol., 74:174-196.

Ogniben, L., 1955. Inverse-graded bedding in primary gypsum of chemical deposition. J. Sediment. Petrol., 25:273-281.

1957. Petrografia della serie solfifera siciliana e considerazioni geologiche relative. Mem. Descr. Carta. Giol. It., 33:1-275.

Orti-Cabo, F., Pueyo-Mur, J. J., Geisler-Cussey, D., and Dulau, N., 1984. Evaporitic sedimentation in the coastal salinas of Santa Pola (Alicante, Spain). Rev. Invest. Geol. Barcelona, 38/39:169-220.

Parea, G. C., and Ricci-Lucchi, F., 1972. Resedimented evaporites in the periadriatic trough. Israel J. Earth Sci., 21:125-141.

Pierre, C., 1974. Contribution a l'étude sédimentologique et isotopique des évaporites messiniennes de la Méditerranée: Implications géodynamiques. [Thesis]. Univ. Paris VI,.

1982. Teneurs en isotopes stables $\left({ }^{18} \mathrm{O},{ }^{2} \mathrm{H},{ }^{13} \mathrm{C},{ }^{34} \mathrm{~S}\right)$ et conditions de genése des évaporites marines: application a quelques milieux actuels et au Messinien de la Méditerranée. [Doct. Thesis]. Univ. Paris-Sud Orsay.

, 1985. Isotopic evidence for the dynamic redox cycle of dissolved sulphur compounds between free and interstitial solutions in marine salt pans. Chem. Geol., 53:191-196.

, 1988. Applications of stable isotope geochemistry to study of evaporites. In Schreiber, B. C. (Ed.), Evaporites and Hydrocarbons, Chap. 6, New York (Columbia Univ. Press), 300-344.

1989. Sedimentation and diagenesis in restricted marine basins. In Fritz, P., and Fontes, J. C. (Eds), Handbook of Environmental Isotope Geochemistry. Part 3: The marine environment, Chap. 8, New York (Elsevier), 257-315.

Pierre, C., and Fontes, J. C., 1978. Isotope composition of Messinian sediments from the Mediterranean sea as indicators of paleoenvironments and diagenesis. In Hsü, K. J., Montadert, L., et al., Init. Repts. DSDP, 42 (Pt. 1), Washington (U.S. Govt. Printing Office), 635-650.

1979. Oxygéne 18, carbone 13, deutérium et soufre 34: marqueurs géochimiques de la diagenése et du paléomilieu évaporitiques du Messinien de la Méditerranée. Bull. Mus. Nat. Hist. Nat., Paris, 4:3-18.

, 1982. Etude isotopique des saumures et des gypses des marais salants de Salin-de-Giraud (Sud de la France). Géol. Méditer., 4: 479-486.

Pierre, C., Ortlieb, L., and Person, A., 1984a. Supratidal evaporitic dolomite at Ojo de Liebre Lagoon: mineralogical and isotopic arguments for primary crystallization. J. Sediment. Petrol., 54:10491061.

Pierre, C., Utrilla-Casal, R., Orti-Cabo, F., and Pueyo-Mur, J. J., 1984b. Preliminary stable isotope investigations in carbonates and gypsum from the coastal Salina of Bonmati (Santa Pola, Alicante, Spain). Rev. Inv. Geol. Barcelona, 38/39:229-235.

Rehault, J. P., Moussat, E., and Fabbri, A., 1987. Structural evolution of the Tyrrhenian back-arc basin. Mar. Geol., 74:123-150.

Ricchiutto, T. E., and McKenzie, J. A., 1978. Stable isotope investigation of Messinian sulfate samples from DSDP Leg $42 \mathrm{~A}$, eastern Mediterranean Sea, In Hsü, K. J., Montadert, L. et al., Init. Repts. DSDP, 42 (Pt. 1), Washington (U.S. Govt. Printing Office), 657-660.

Ricci-Lucchi, F., 1973. Resedimented evaporites: indicators of slope instability and deep basins conditions in Periadriatic Messinian (Apennines Foredeep, Italy). In Drooger, C. W. (Ed.), Messinian Events in the Mediterranean, Proc. K. Ned. Akad. Wet. Ser. B. Geod. Sci., 7: 142-149. 
Rouchy, J. M., 1976. Mise en évidence de nannoplancton calcaire dans certains types de gypse finement laminé (balatino) du Miocéne terminal de sicile et conséquences sur la genése des évaporites méditerranéennes de cet age. C.R. Acad. Sci. Paris, 282:13-16.

,1982. La genése des évaporites messiniennes de Méditerranée. Mém. Mus. Nat. Hist. Nat., Paris, 1-267.

Rouchy, J. M., and Pierre, C., 1979. Données sédimentologiques et isotopiques sur les gypses des séries évaporitiques messiniennes d'Espagne méridionale et de Chypre. Rev. Géogr. Phys. Géol. Dyn., 21: 267-280.

Rouchy, J. M., Orszag-Sperber, F., Bizon, G., and Bizon, J. J., 1980; Mise en évidence d'une phase d'émersion fini-messinienne dans le bassin de Pissouri (Chypre): une modalité de passage Miocéne-Pliocéne en Méditerranée orientale. C. R. Acad. Sci. Paris, 291:729-732.

Rouchy, J. M., and Monty, C.L.V., 1981. Stromatolites and cryptalgal laminites associated with Messinian gypsum of Cyprus. In Monty, C.L.V. (Ed.), Phanerozoic stromatolites. Heidelberg (Springer-Verlag), $155-178$.

Rouchy, J. M., Bernet-Rollande, M. C., and Maurin, A. F., 1986. Pétrographie descriptive des évaporites. Applications sur le terrain, en subsurface et au laboratoire. In Les séries a évaporites en exploration pétroliére. Vol. 1 : Méthodes géologiques. Paris (Ed. Technip), 73-122.

Savin, S. M., Keller, G., Killingley, J. S., Shaughnessy, J. L., Sommer, M. A., Vincent, E., and Woodruff, F., 1981. Miocene benthic foraminiferal isotope records: a synthesis. Mar. Micropaleontol., 6:423450.

Schlanger, W., and Bolz, H., 1977. Clastic accumulation of sulfates evaporites in deep-water. J. Sediment. Petrol., 47:600-610.

Schreiber, B. C., 1974. Upper Miocene (Messinian) evaporites deposits of the Mediterranean basin and their depositional environments. [Dissert.], Rensselaer Polytechnic Inst., New York.

1978. Environments of sub-aqueous evaporites. In Dean, W. E., and Schreiber, B. C. (Eds.), SEPM short course 4, Oklahoma City, 1-5.
Schreiber, B. C., Friedman, G. M., Decima, A., and Schreiber, E., 1976. Depositional environments of upper Miocene (Messinian) evaporite deposits of the Sicilian basin. Sedimentology, 23:729-760.

Shackleton, N., Hall, M. A., and Boersma, A., 1984. Oxygen and carbon isotope data from Leg 74 foraminifera, In Moore, T. C., Jr., Rabinowitz, P. D., et al., Init. Repts., DSDP, 74; Washington (U.S. Govt. Printing Office), 599-612.

Sharma, T., and Clayton, R. N., 1965. Measurement of ${ }^{18} \mathrm{O} /{ }^{16} \mathrm{O}$ ratios of total oxygen of carbonates. Geochim. Cosmochim. Acta, 29: $1347-1353$.

Shearman, D. J., 1966. Origin of marine evaporites by diagenesis. Inst. Mining Metallurg. Trans., 717:208-215. 1971. Marine evaporites. The calcium sulfate facies. Univ. Calgary, A.A.P.G. Seminar, unpubl. rept., 65 p. 1983. Syndepositional and Late Diagenetic Alteration of Primary Gypsum to Anhydrite. Sixth Intern. Symposium on Salt, Salt Institute, vol. L, 41-50.

Sheppard, S.M.F., and Schwarcz, H. P., 1970. Fractionation of carbon and oxygen isotopes and magnesium between coexisting metamorphic calcite and dolomite. Contr. Mineral. Petrol, 26:161-198.

Vai, G. B., and Ricci-Lucchi, F., 1978. The Vena del Gesso in Northern Apennines: growth and mechanical breakdown of gypsified algal crusts. In Catalano, R., et al. (Eds.), Messinian evaporites in the Mediterranean. Mem. Soc. Geol. It., 16:217-249.

Vincent, E., and Berger, W. H., 1980. The magnetic epoch 6-carbon shift: a change in the ocean's ${ }^{13} \mathrm{C} /{ }^{12} \mathrm{C}$ ratio, 6.2 million years ago. Mar. Micropaleontol., 5:185-203.

Vonder Haar, S. P., 1976. Evaporites and algal mats at laguna Mormona, Pacific coast, Baja California, Mexico. (Dissert.). Univ. Southern California.

Date of initial receipt: 12 January 1988

Date of acceptance: 21 November 1988

Ms 107B-131 


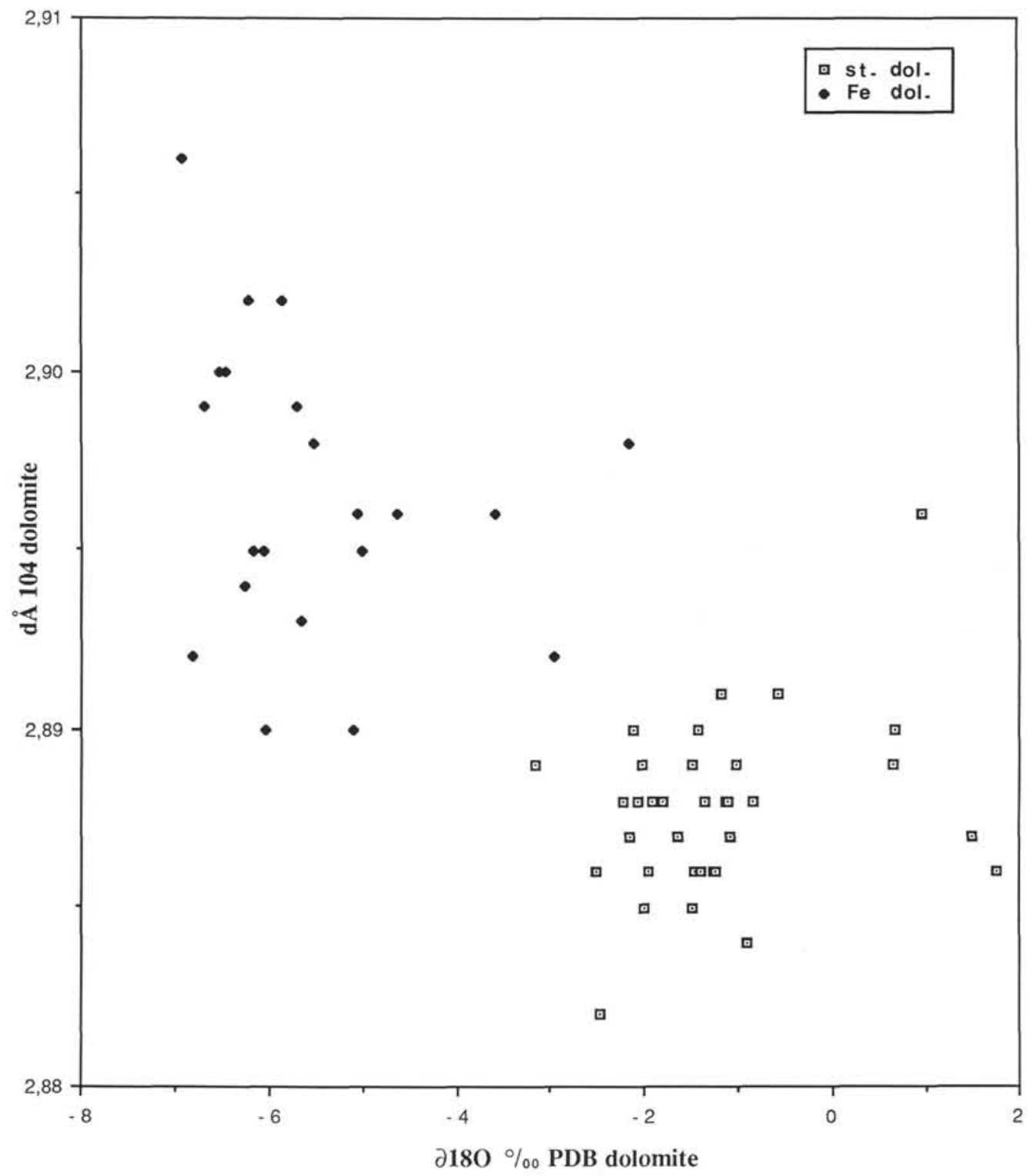

Figure 7. Relationship between $\delta^{18} \mathrm{O}$ and $\mathrm{d}_{104}$ values of stoichiometric dolomites (st. dol.) and iron-rich dolomites (Fe dol.) at ODP Hole 652A. 


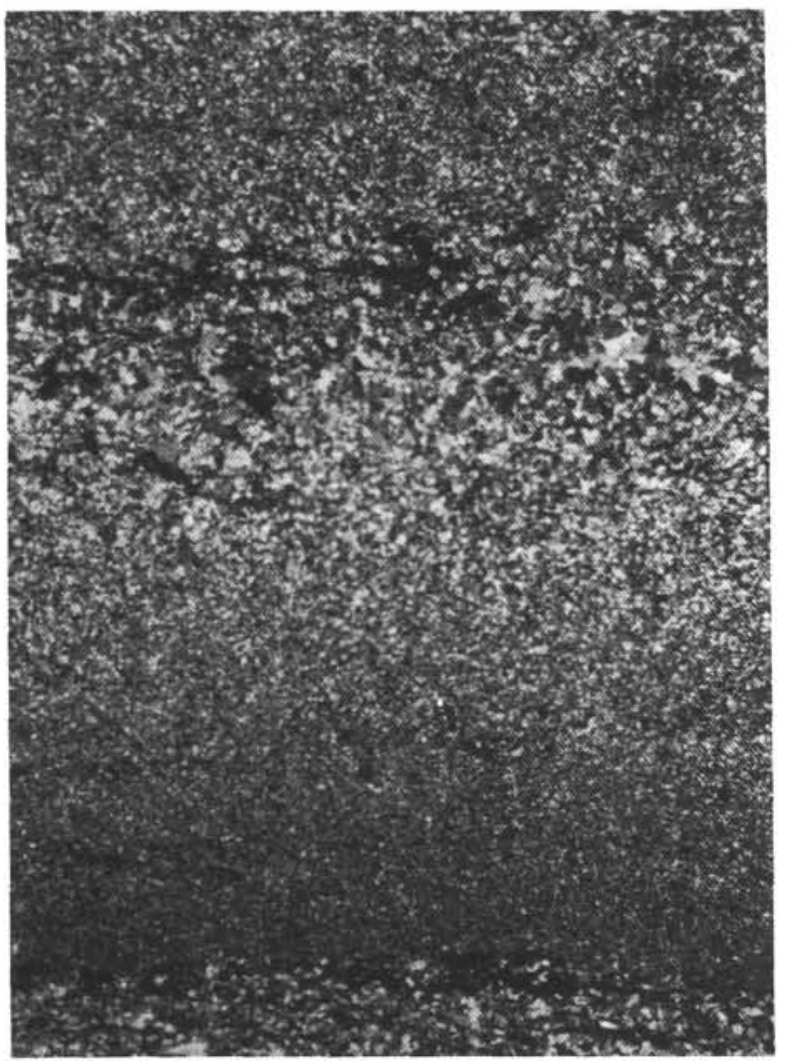

1

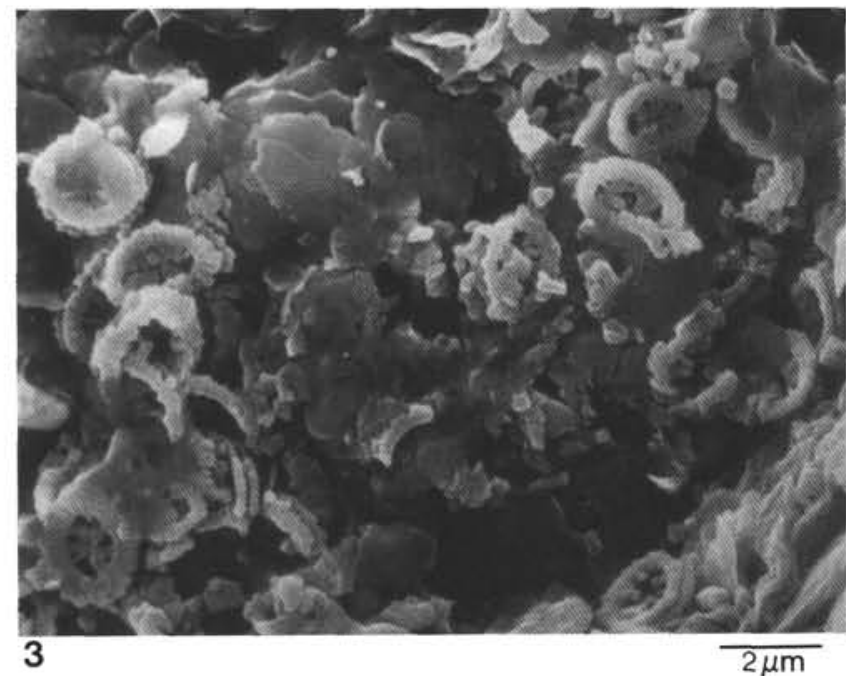

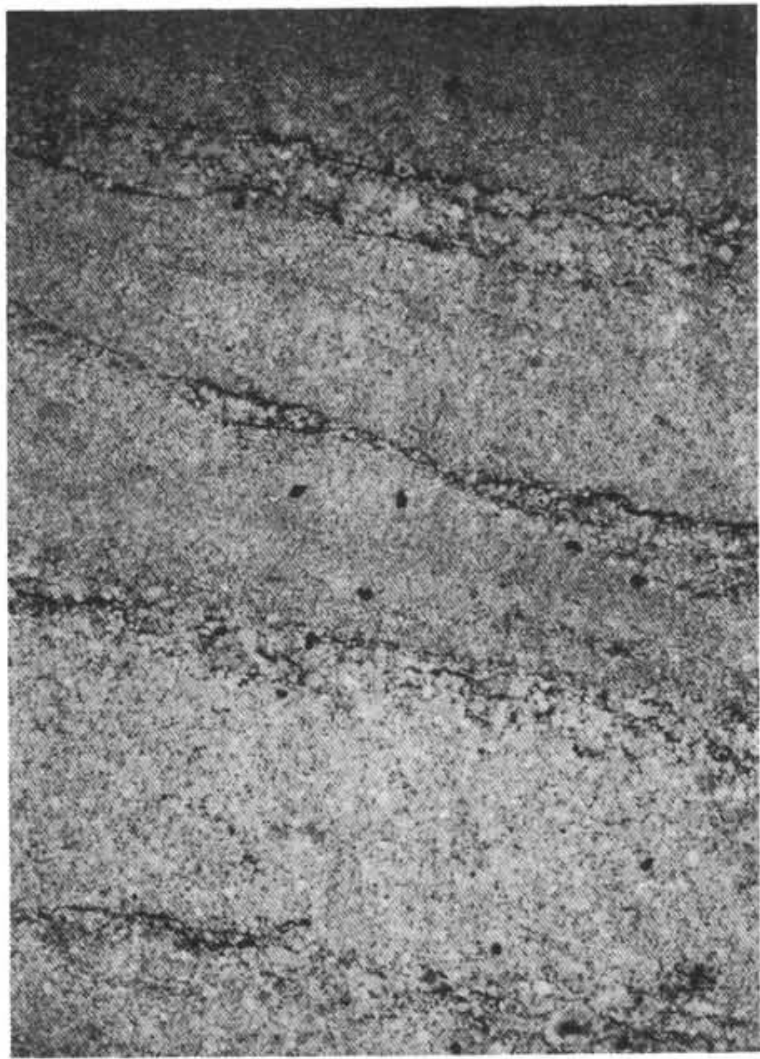

2

$100 \mu \mathrm{m}$

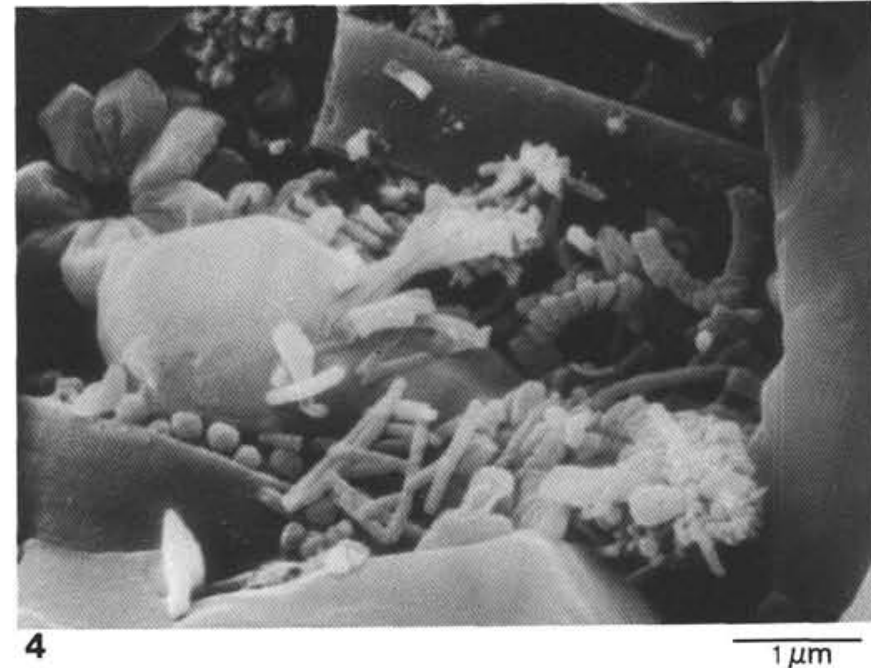

Plate 1. Holes 653B and 654A: sulfates. 1. Regular-laminated gypsum with reverse graded-bedding of each individual laminae (654A-32-1, $132-135 \mathrm{~cm}$ ). Thin-section photomicrograph: crossed nicols; scale bar $=100 \mu \mathrm{m}$. 2. Regular laminated gypsum with different laminae boundaries: regular, truncated, diffuse. In the upper part, a second-order lamination is distinguished (653B-25-1, 42-44 cm). Thin-section photomicrograph: plain light; scale bar $=100 \mu \mathrm{m}$. 3. Intergypsum laminae composed by clays and monospecific nannoplankton (Reticulofenestra sp.) (653B-25-1, 68-70 cm). SEM photograph: scale bar $=2 \mu \mathrm{m}$. 4. Biogenic intergypsum laminae with an association of monospecific nannoplankton (Coccolithus sp.), fragmented pennate diatoms, probably reworked Discoasteridae and small filaments and grains of presumed bacterial origin (654A-34-4, $33-34 \mathrm{~cm})$. SEM photograph: scale bar $=1 \mu \mathrm{m}$. 

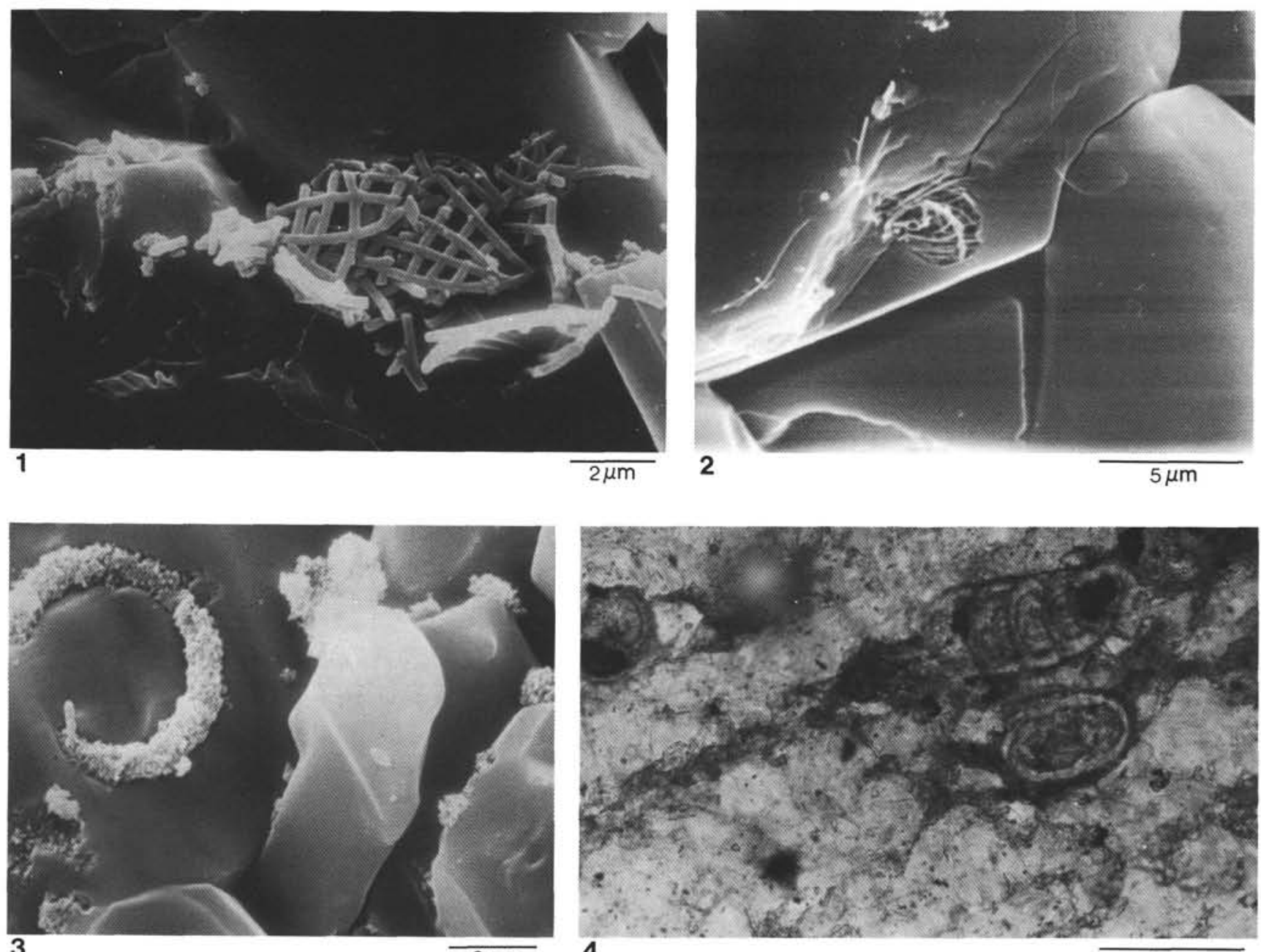

3
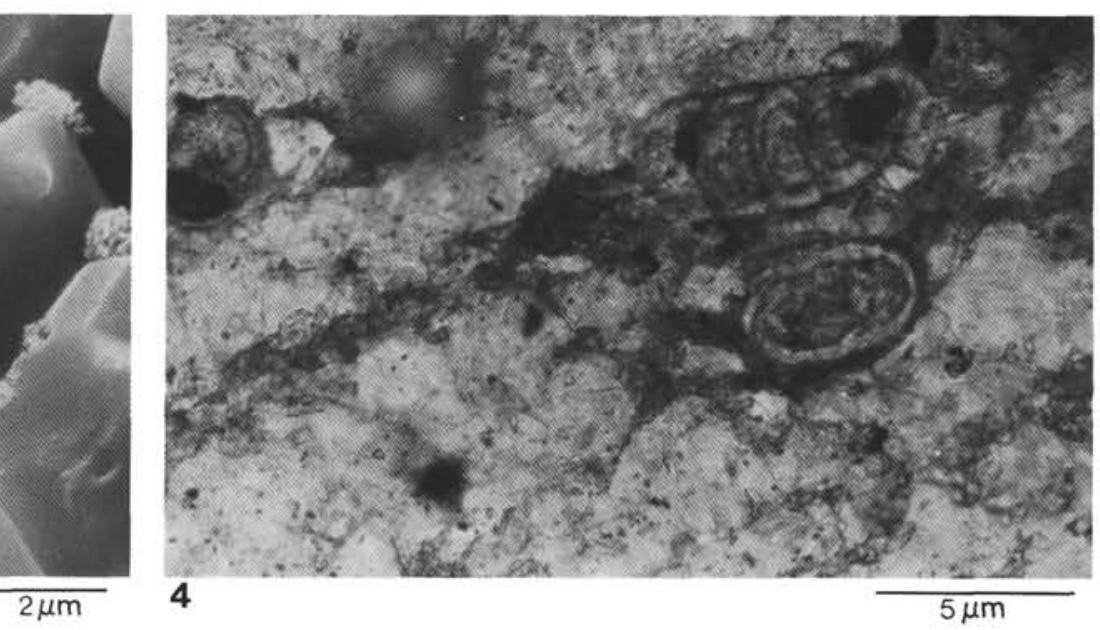

Plate 2. Hole 654A: sulfates. 1. Bacterial filaments arranged in a pseudoreticulated structure between gypsum crystals; coccoliths may be partly enclosed in the gypsum (654A-34-4,33-34 cm). SEM photograph: scale bar $=2 \mu \mathrm{m}$. 2. Filaments (probably bacterial) in an open cavity within a gypsum crystal (654A-34-4, 33-34 cm). SEM photograph: scale bar $=5 \mu \mathrm{m} . \quad 3$. Regular-laminated gypsum. Globular or annular aggregates of bacteria(?) associated, sometimes enclosed within gypsum crystals (654A-33-4, 33-34 cm). SEM photograph: scale bar $=2 \mu \mathrm{m}$. 4 . Regular-laminated gypsum. Foraminifers enclosed in the lowermost part of a gypsum laminae (654A-31-1, 139-141 cm). Thin-section photomicrograph: plain light; scale bar $=5 \mu \mathrm{m}$. 


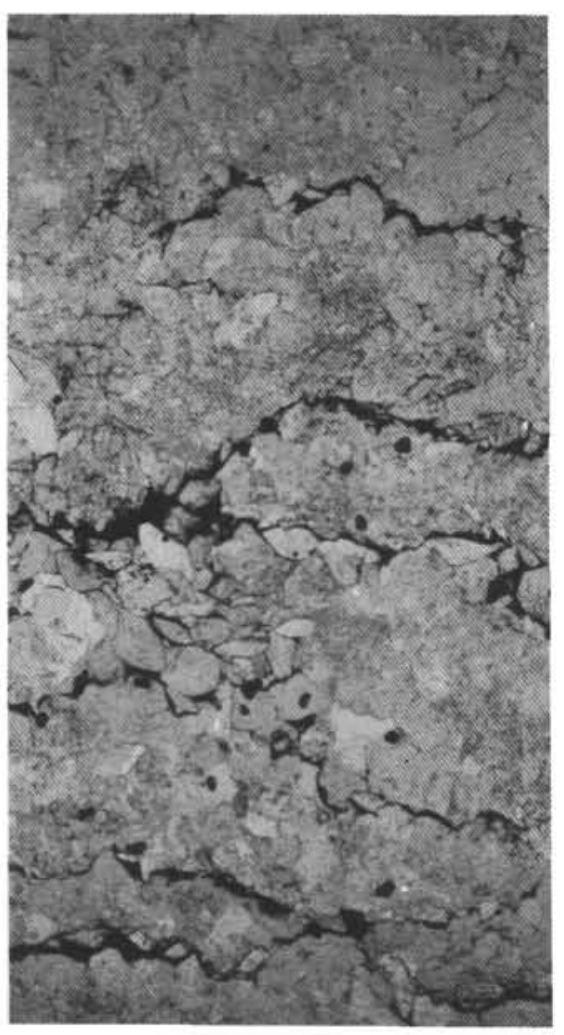

1

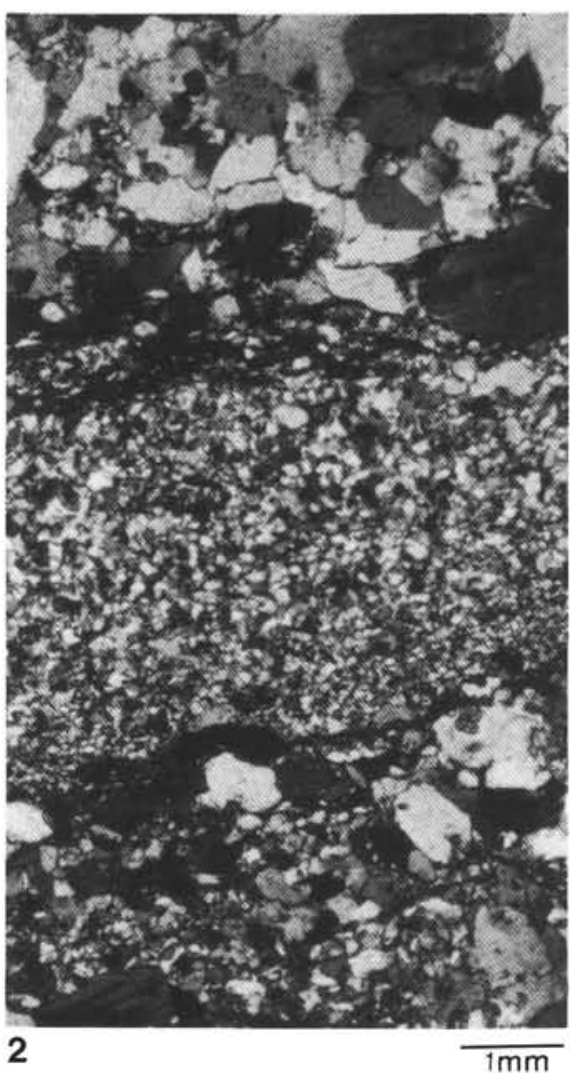

$1 \mathrm{~mm}$

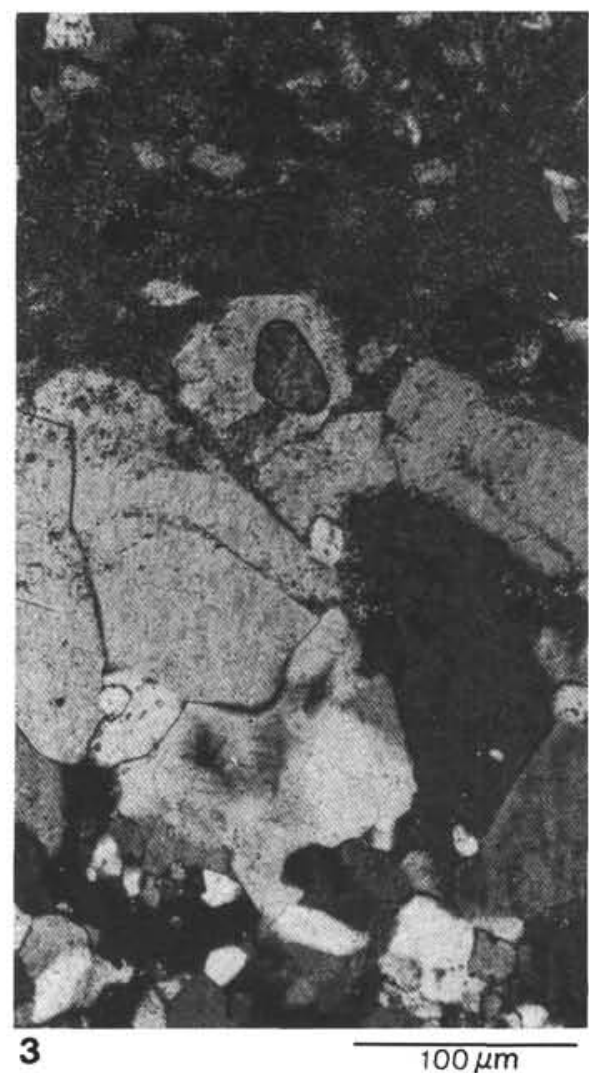

$100 \mu \mathrm{m}$

Plate 3. Hole 654A: sulfates. 1. Wavy-laminated gypsum. Contorted to subnodular structure; the discontinuous layers are composed of interlocked crystals displaying a well-defined lenticular habit. $(654 \mathrm{~A}-28-1,64-67 \mathrm{~cm})$. Thin-section photomicrograph: plain light; scale bar $=1 \mathrm{~mm}$. 2. Wavy-laminated gypsum. Two distinct types of gypsum laminae with different crystal size; the coarser type may be partly of detrital origin (654A-33-1, $80-82 \mathrm{~cm}$ ). Thin-section photomicrograph: crossed nicols; scale bar $=1 \mathrm{~mm}$. 3. Wavy-laminated gypsum. Contact between two gypsum laminae; the uppermost part of the lower laminae is composed by closely interlocked crystals with upward chevron structures underlined by carbonate inclusions (654A-28-1, 64-67 cm). Thin-section photomicrograph: crossed nicols; scale bar $=100 \mu \mathrm{m}$. 

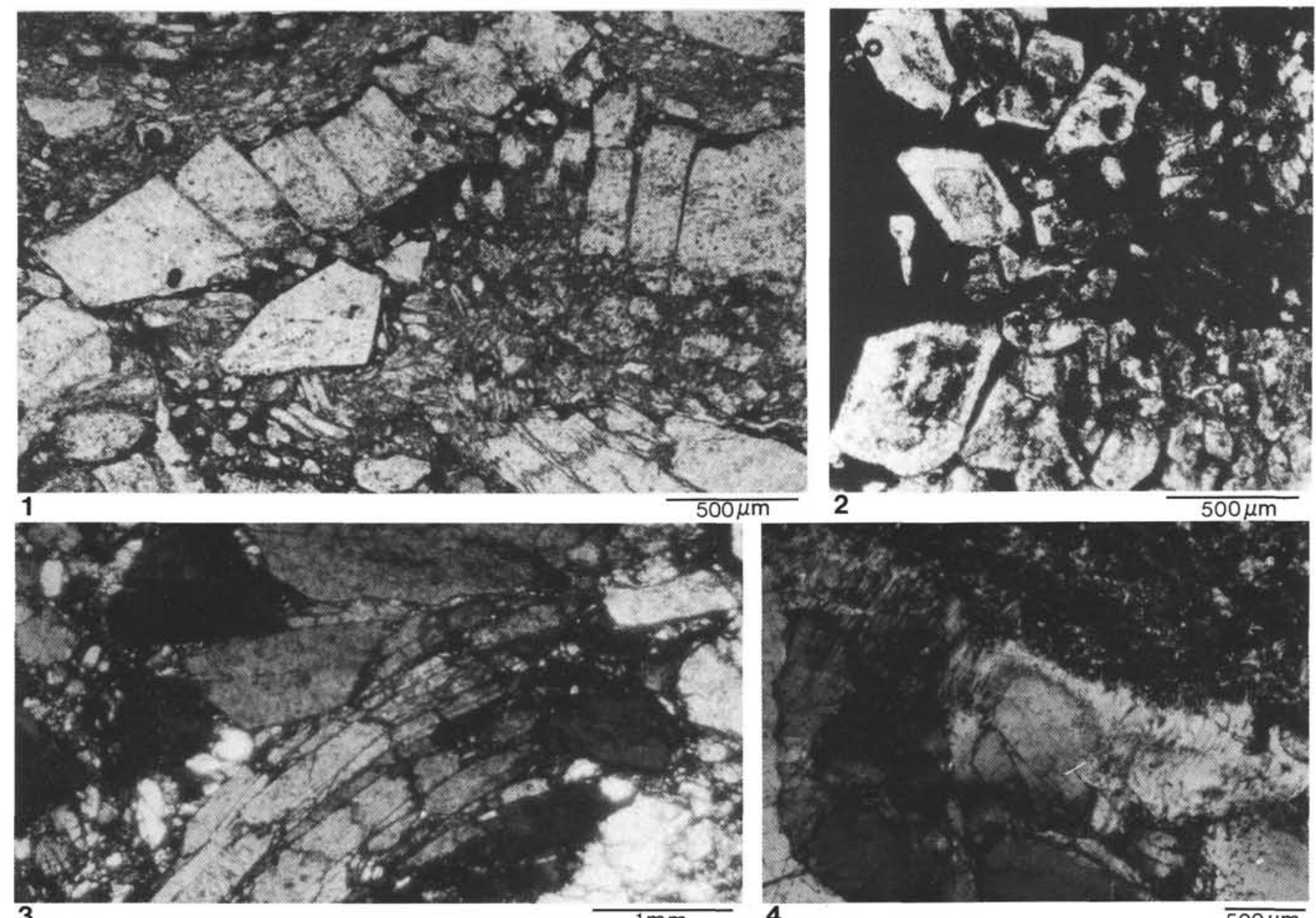

3

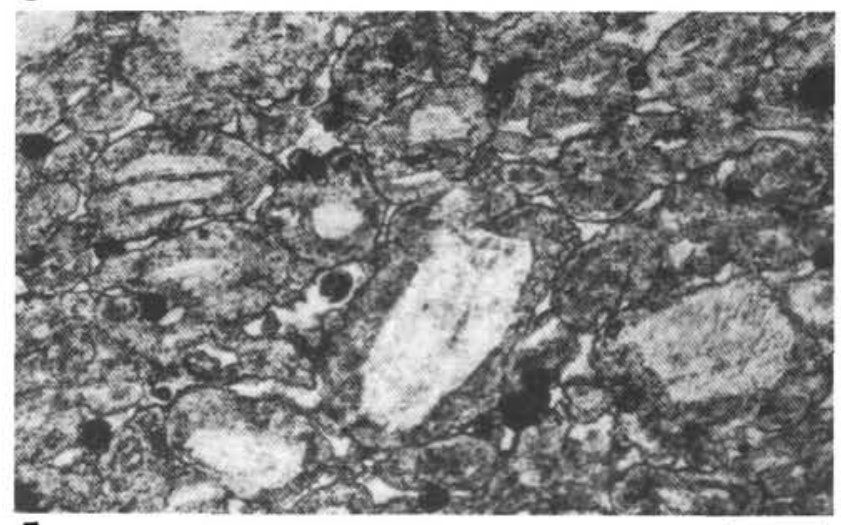

$1 \mathrm{~mm} \quad 4$

$500 \mu \mathrm{m}$

5

$\overline{200 \mu \mathrm{m}}$
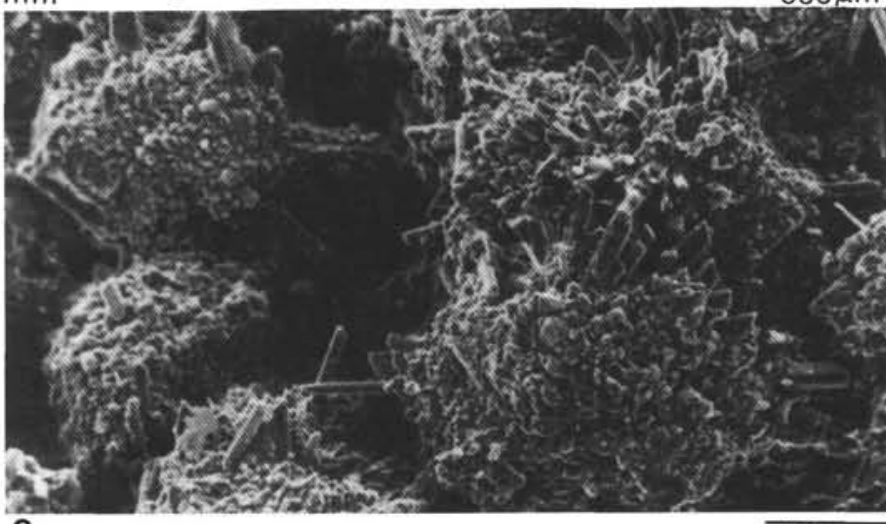

6

$100 \mu \mathrm{m}$

Plate 4. Holes 653B and 654A: sulfates. 1. Reworked gypsum. Gypsarenites with large fragments of crystals broken along the main cleavage planes; one of them is affected by intracrystalline breakage $(653 \mathrm{~B}-28-2,70-72 \mathrm{~cm})$. Thin-section photomicrograph: crossed nicols; scale bar = $500 \mu \mathrm{m}$. 2. Reworked gypsum. Euhedral crystals with tabular to lenticular shapes and overgrowth structures. (653B-27-4, 101-103 cm). Thin-section photomicrograph: plain light; scale bar $=500 \mu \mathrm{m}$. 3. Reworked and deformed gypsum crystals with internal breakage and curvature of the cleavage planes. (653B-28-1, 134-136 cm). Thin-section photomicrograph: crossed nicols; scale bar $=1 \mathrm{~mm}$. 4. Reworked gypsum. Fibrous alteration of gypsum clasts along the intercrystalline boundaries in the upper part of a gypsarenite layer (653B-28-1, 120-122 cm). Thin-section photomicrograph: crossed nicols; scale bar $=500 \mu \mathrm{m}$. 5. Gypsum spherulites with radial-fibrous cortex around detrital gypsum fragments; a few spherulites lack nucleus. The bulk sediment is characterized by the absence of cement between the spherulites (653B-28-2, 70-72 cm). Thin-section photomicrograph: plain light; scale bar $=200 \mu \mathrm{m}$. 6. Spherulitic layer with outward projection of the gypsum crystals into the interspherulitic voids (653B-28-1, $120-122 \mathrm{~cm})$. SEM photograph: scale bar $=100 \mu \mathrm{m}$. 

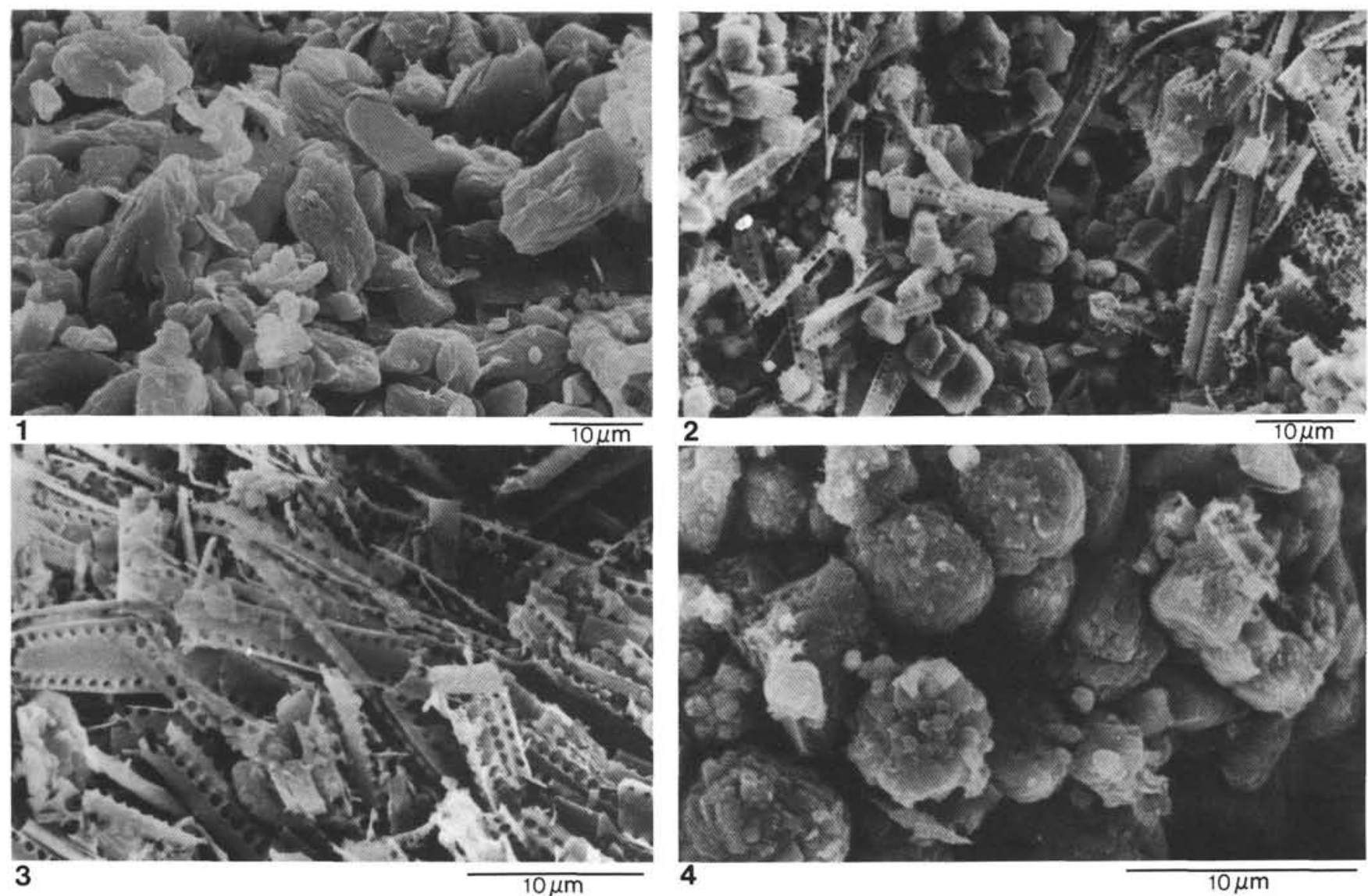

Plate 5. Hole 654A: carbonates. 1. Carbonate intercalated within gypsum. Calcareous mudstone with subhedral to euhedral crystals with occasional internal voids $(654 \mathrm{~A}-28-2,10-13 \mathrm{~cm})$. SEM photograph: scale bar $=10 \mu \mathrm{m} . \quad 2$. Carbonates from the infragypsum formation (Hole $654 \mathrm{~A})$. Concentration of marine pennate diatoms associated with dolomite displaying two distinct crystal habits: rounded grains and euhedral rhombs (654A-39-2, 78-79 cm). SEM photograph: scale bar $=10 \mu \mathrm{m}$. 3. Pure diatomitic laminae with pennate diatoms of genus Thalassionema $(654 \mathrm{~A}-39-2,78-79 \mathrm{~cm})$. SEM photograph: scale bar $=10 \mu \mathrm{m} \quad$ 4. Detail of the morphology of the round crystals of dolomite $(654 \mathrm{~A}-39-2,78-79 \mathrm{~cm})$. SEM photograph: scale bar $=10 \mu \mathrm{m}$. 

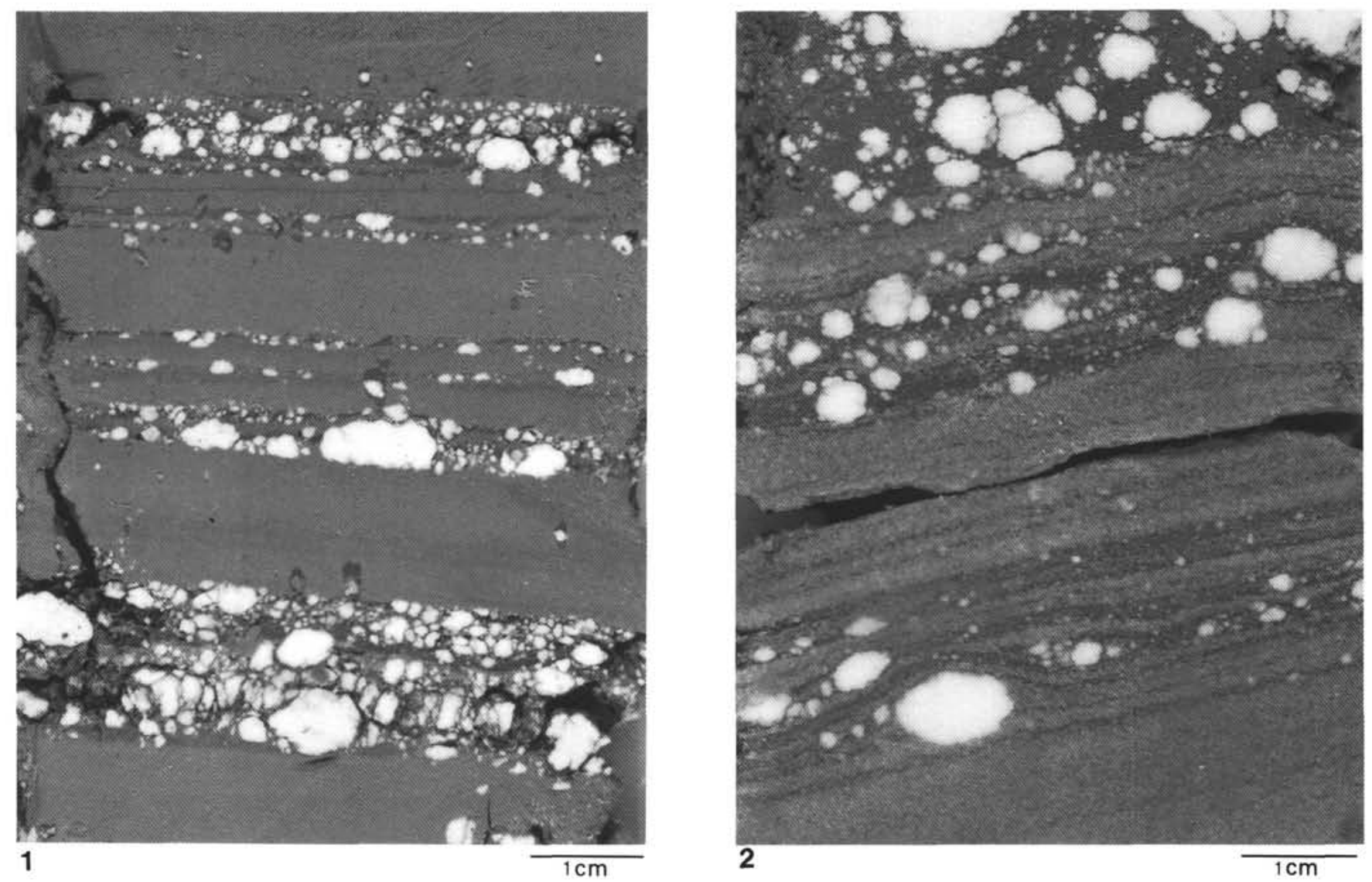

Plate 6. Hole 652A: sulfates. 1. Typical centimeter-thick layers of nodular anhydrite. The layers display sharp boundaries but a few nodules are also scattered in the silty host-sediment. In the lowermost layer, nodules with subvertical orientation appear deformed around individual nodules $(652 \mathrm{~A}-38-3,69-77 \mathrm{~cm})$. Close-up photograph: scale bar $=1 \mathrm{~cm}$. 2. Nodular and laminated anhydrite where lamination is deformed around nodules (652A-44-3, 70-77 cm). Close-up photograph: scale bar $=1 \mathrm{~cm}$. 


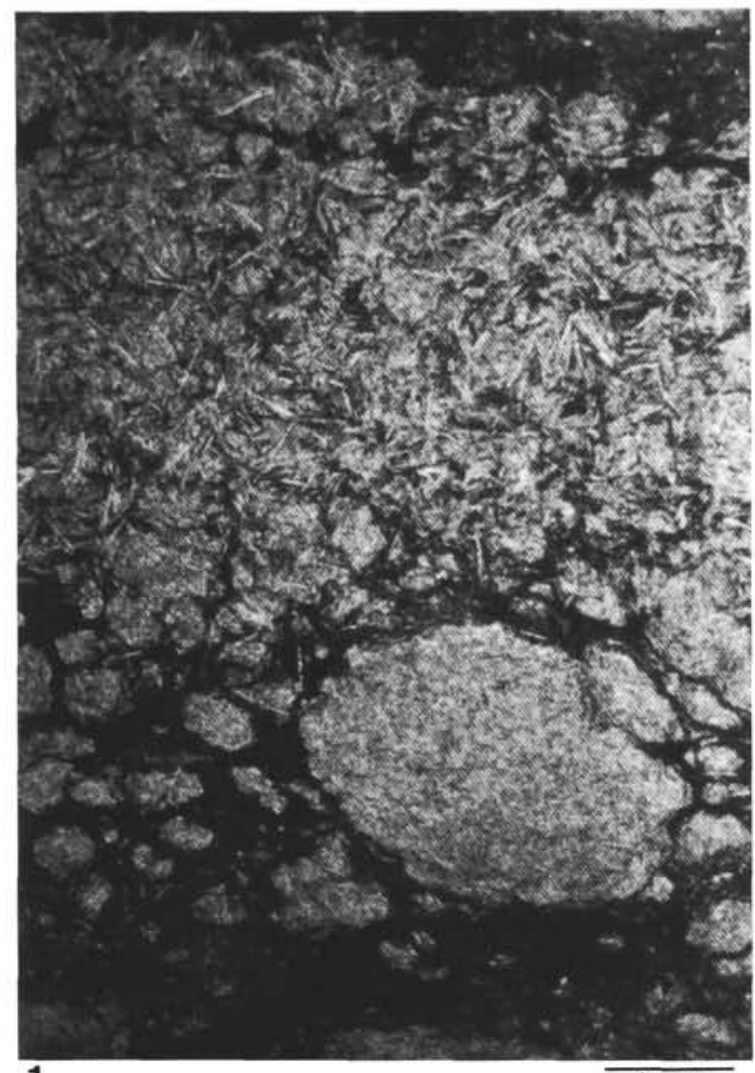

1

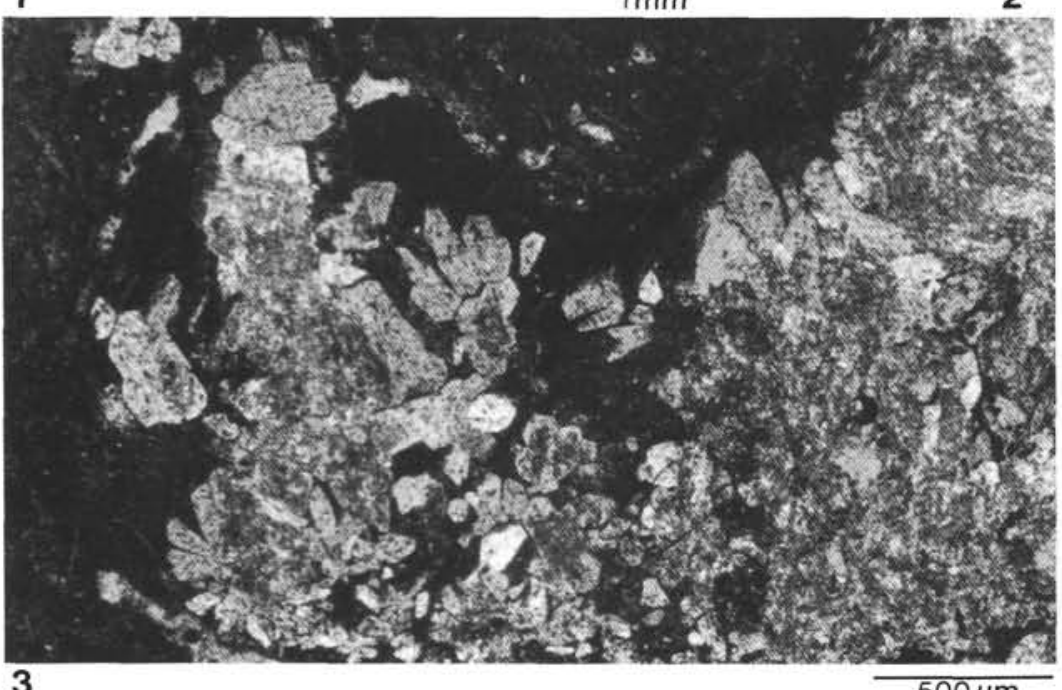

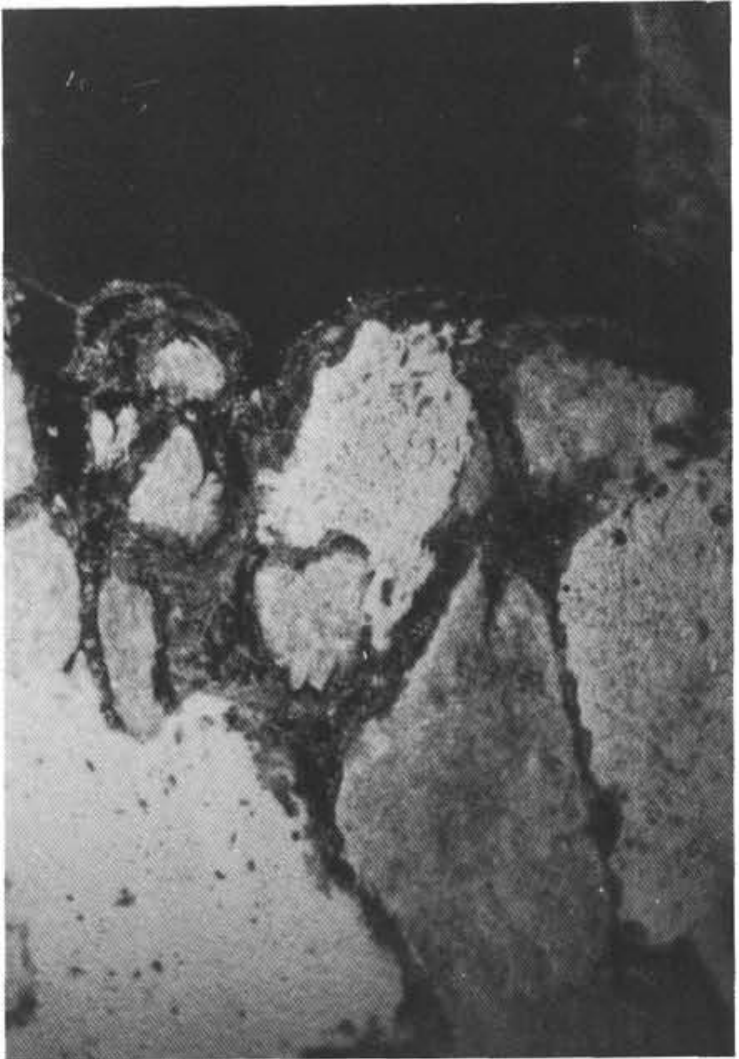

2

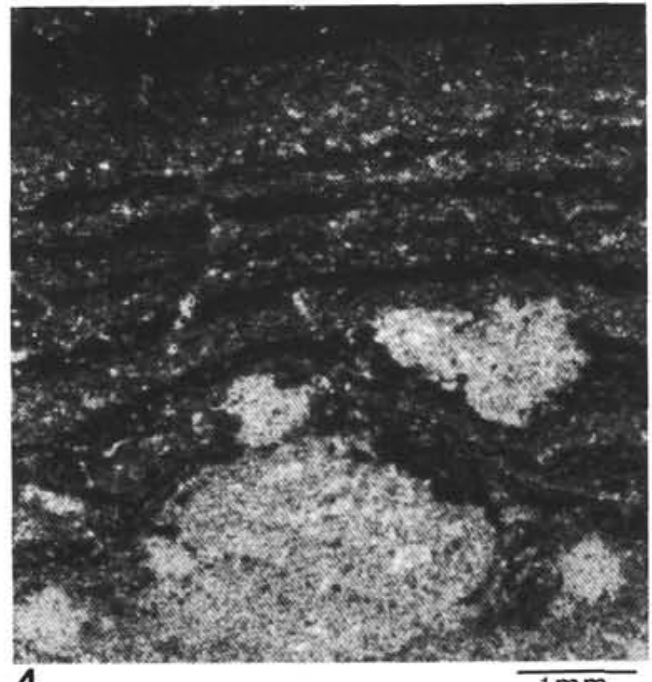

4

$1 \mathrm{~mm}$

Plate 7. Hole 652A: sulfates. 1. Laminated anhydrite with the typical felted texture where outlines of angular grains (probable gypsum precursor) are recognized $(652 \mathrm{~A}-44-3,59-62 \mathrm{~cm})$. Thin-section photomicrograph: plain light; scale bar $=1 \mathrm{~mm} .2$. Nodular anhydrite partly invaded by gypsum which forms rims around anhydrite nodules and penetrates along the nodule boundaries (652A-38-3, 41-43 cm). Thin-section photomicrograph: plain light; scale bar $=1 \mathrm{~mm}$. 3. Secondary gypsum; the euhedral crystals develop around anhydrite nodules, or in the host-sediment as scattered crystals or stellate aggregates $(652 \mathrm{~A}-37-4,74-76 \mathrm{~cm})$. Thin-section photomicrograph: crossed nicols; scale bar $=500 \mu \mathrm{m}$. 4. Anhydrite nodules (pseudomorphs after gypsum?) developed displacively into dark finely-laminated algal sediment $(652 \mathrm{~A}-37-4,36-38 \mathrm{~cm})$. Thin-section photomicrograph: crossed nicols; scale bar $=1 \mathrm{~mm}$. 

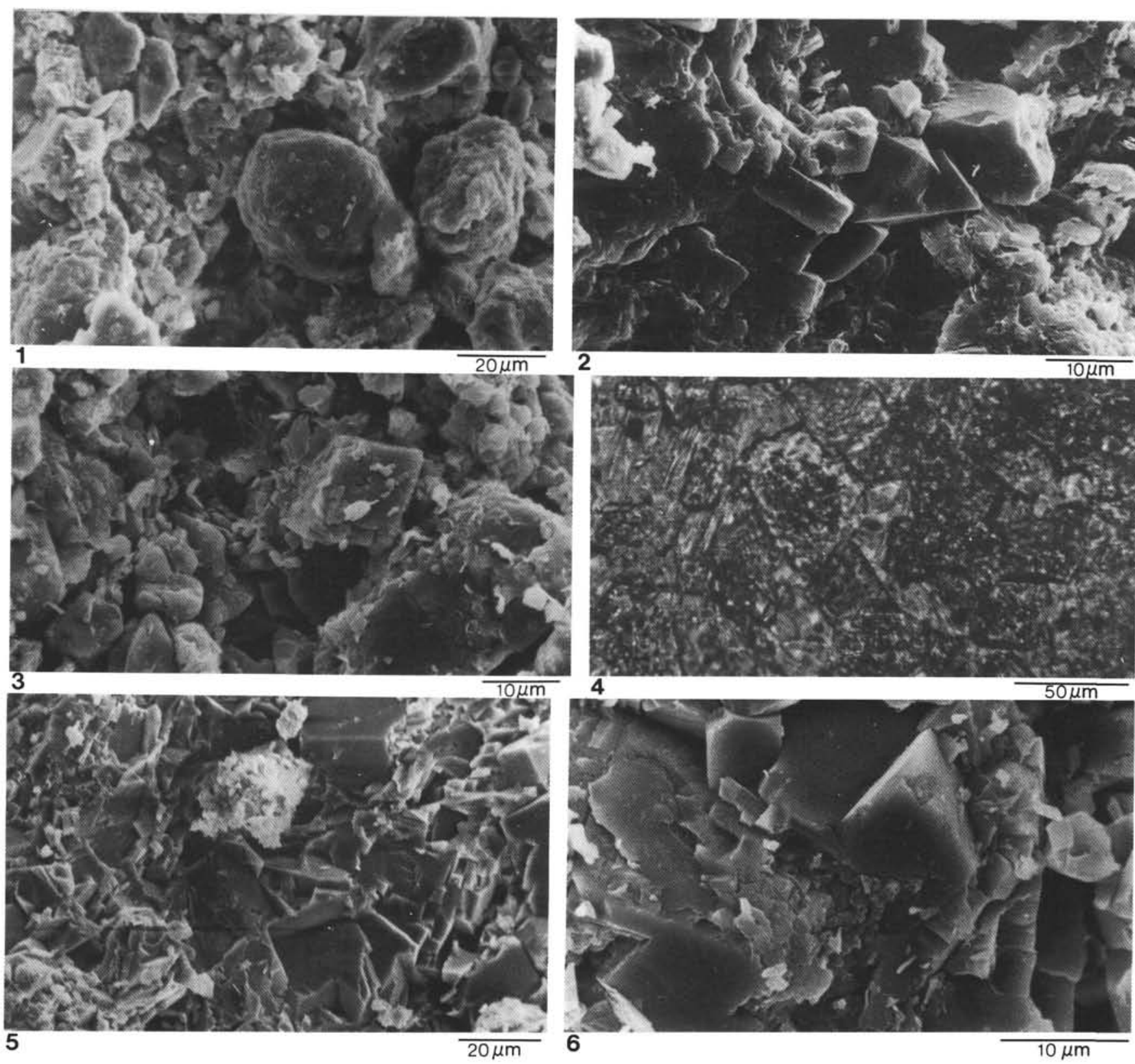

Plate 8. Hole 652A: carbonates. 1. Two morphologies of carbonates: round grains (1) and rhombs (2); the round grains may be coated by euhedral overgrowths (652A-34-CC, $2-4 \mathrm{~cm})$. SEM photograph: scale bar $=20 \mu \mathrm{m}$. 2. Euhedral dolomite crystals $(652 \mathrm{~A}-50-2,36-39 \mathrm{~cm})$. SEM photograph: scale bar $=10 \mu \mathrm{m}$. 3. Euhedral rhombs of iron-rich dolomite (arrow) in calcareo-dolomitic siltstone $(652 \mathrm{~A}-34-\mathrm{CC}, 2-4 \mathrm{~cm})$. SEM photograph: scale bar $=10 \mu \mathrm{m}$. 4. Euhedral to subhedral iron-rich dolomite associated with anhydrite (652A-61-4, 36-38 cm). Thin-section photomicrograph: plain light; scale bar $=50 \mu \mathrm{m}$. 5. Euhedral rhombs of iron-rich dolomite associated with anhydrite $(652 \mathrm{~A}-31-4,36-38 \mathrm{~cm})$. SEM photograph: scale bar $=20 \mu \mathrm{m}$. 6. Detailed view of the iron-rich dolomite crystals including particles (mainly anhydrite) of the host sediment (652A-31-4, 36-38 cm). SEM photograph: scale bar $=10 \mu \mathrm{m}$. 